\title{
Dynamic correlation between stock market and oil prices: The case of oil-importing and oil-exporting countries
}

\author{
Stavros Degiannakis ${ }^{1}$, George Filis ${ }^{2 *}$, Christos Floros ${ }^{3}$ \\ ${ }^{1,2,3}$ Department of Economics, University of Portsmouth, \\ Portsmouth Business School, Portsmouth, \\ Portland Street, \\ PO1 3DE, United Kingdom \\ *Corresponding author: \\ email: George.Filis@port.ac.uk, \\ tel: 0044 (0) 2392844828 , \\ fax: 0044 (0) 844037
}

\begin{abstract}
The paper investigates the time-varying correlation between stock market prices and oil prices for oil-importing and oil-exporting countries. A DCC-GARCH-GJR approach is employed to test the above hypothesis based on data from six countries; Oil-exporting: Canada, Mexico, Brazil and Oil-importing: USA, Germany, Netherlands. The contemporaneous correlation results show that i) although time-varying correlation does not differ for oil-importing and oil-exporting economies, ii) the correlation increases positively (negatively) in respond to important aggregate demand-side (precautionary demand) oil price shocks, which are caused due to global business cycle's fluctuations or world turmoil (i.e. wars). Supply-side oil price shocks do not influence the relationship of the two markets. The lagged correlation results show that oil prices exercise a negative effect in all stock markets, regardless the origin of the oil price shock. The only exception is the 2008 global financial crisis where the lagged oil prices exhibit a positive correlation with stock markets. Finally, we conclude that in periods of significant economic turmoil the oil market is not a safe haven for offering protection against stock market losses.
\end{abstract}

JEL: C5 ; G1; Q4

Keywords: oil prices; oil price shocks; stock market returns; DCC-GARCH; dynamic correlation. 


\section{Introduction}

This paper investigates the contemporaneous and lagged time-varying correlation between stock market prices and oil prices for oil-importing and oil-exporting countries considering the origin of oil price shocks. In particular, we consider Kilian's (2009) and Hamilton's (2009) origins of oil price shocks (aggregate demand-side shock, precautionary demand shock and supply-side shock $)^{1}$. The main events, occurred during the period of study, are tied up with the origins of oil price shocks. Despite the fact that oil price effects on macroeconomic variables have been extensively studied ${ }^{2}$, the literature on the relationship between stock market and oil prices is still growing. Nevertheless, there are very few studies on the dynamic correlation between these two markets. A first approach on the dynamic comovements between oil prices and stock markets was performed by Ewing and Thomson (2007), using the cyclical components of oil prices and stock prices. They concluded that crude oil prices are pro-cyclical and lag stock prices by 6 months. Bharn and Nikolova (2010) have also examined the dynamic correlation between stock market and oil prices, in Russia, using a bivariate EGARCH model. They identified three major events (i.e. September $11^{\text {th }}$, 2001 terrorist attack, war in Iraq 2003 and the civil war in Iraq in 2006) which caused a negative correlation between the Russian stock market and the oil prices. Aloui and Jammazi (2009) applied a univariate regime-switching EGARCH model to examine the relationship between crude oil shocks and UK, French and Japanese stock markets. They detected two episodes of series behaviour, one relative to low mean and high variance regime and the other to high mean and low variance regime, and provided evidence that common recessions

\footnotetext{
${ }^{1}$ According to Kilian (2009), aggregate demand-side shocks occur due to global business cycle's fluctuations, precautionary demand shocks occur due to the uncertainty of future oil supply based on the expectations of future oil demand, and supply-side shocks are exogenous shocks and occur due to reduction of crude oil availability.

${ }^{2}$ See for example, Hamilton (1983), Burbridge and Harrison (1984), Gisser and Goodwin (1986), Hamilton (1988a, 1998b), Mork et al. (1994), Lee et al. (1995), Ferderer (1996), Hondroyiannis and Papapetrou (2001), Papapetrou (2001), Jones et al. (2004), Hamilton and Herrera (2004), Huntington (2007), Kilian (2008), Jimenez-Rodriguez (2009), Berument et al. (2010), Du, He and Wei (2010), Korhonen and Ledyaeva (2010), Hammoudeh, Bhar and Thompson ( 2010) and Doğrul and Soytas (2010).
} 
coincide with the low mean and high variance regime. Furthermore, Lee and Chiou (2011) applied a univariate regime-switching GARCH model to examine the relationship between WTI oil prices and S\&P500 returns. They concluded that when there are significant fluctuations in oil prices, the resultant unexpected asymmetric price changes lead to negative impacts on S\&P 500 returns, but the result does not hold in a regime of lower oil price fluctuations. Cifarelli and Paladino (2010) applied a multivariate CCC-GARCH model and provided evidence that oil price shifts are negatively related to stock price and exchange rate changes. Finally, Choi and Hammoudeh (2010) applied a symmetric DCC-GARCH model and indicated increasing correlations among Brent oil, WTI oil, copper, gold and silver but decreasing correlations with the S\&P500 index. Chang et al. (2010) based on a symmetric DCC-GARCH model also investigated the conditional correlations and volatility spillovers between crude oil (WTI and Brent markets) and FTSE100, NYSE, Dow Jones and S\&P500 stock indices.

In the present study a robust quantitative technique is employed, namely Dynamic Conditional Correlation asymmetric GARCH, or DCC-GARCH-GJR, that has not been applied before to investigate the time-varying correlation between oil and stock market prices, considering the origin of the oil price shock. In addition, this paper belongs to a limited number of studies which make a distinction on the relationship between oil prices and stock market between oil-importing and oil-exporting countries, (see for example Apergis and Miller, 2009 and Park and Ratti, 2008). More specifically, Park and Ratti (2008) having examined 13 European countries, they concluded that positive oil price shocks cause positive returns for the Norwegian stock market (oil-exporter), whereas the opposite happens to the rest of the 13 European stock markets (oil-importers). Apergis and Miller (2009), on the other hand, concluded that stock markets (both from oil-importing and oil-exporting countries) tend not to react to oil price shocks (either positive or negative). 
The DCC-GARCH-GJR framework is employed using data, from 1987 to 2009, for six countries; three oil-exporting: Canada, Mexico, Brazil and three oil-importing: US, Germany, Netherlands. The DCC-GARCH-GJR can be successively estimated for large timevarying covariance matrices, while it requires the estimation of less number of parameters than other multivariate GARCH-GJR models.

There is a trend in financial literature for time varying correlation between oil prices and stock markets. The present paper contributes to this trend. To the best of authors' knowledge, this is the first paper that examines the dynamic correlation between stock market and oil prices using an asymmetric DCC-GARCH model and thus, this paper significantly adds to the existing and growing literature of this research area ${ }^{3}$. In addition, this paper provides a detailed analysis of the changes in the time-varying correlation between oil prices and stock market returns to address all events that are tied up with the origins of oil price shocks.

The rest of the paper is organised as follows: Section 2 present the oil price chronology for the period under consideration, section 3 reviews the literature, section 4 describes the model and data used, section 5 presents the empirical findings of the research and, finally, section 6 concludes the study.

\section{Oil price chronology}

Figure 1 presents the Brent crude oil prices, in dollars, from January 1987 to September 2009. Oil price movements show some important peaks and troughs during the

\footnotetext{
${ }^{3}$ Aloui and Jammazi (2009) and Lee and Chiou (2011) applied univariate regime-switching models. Cifarelli and Paladino (2010) proposed a constant conditional correlation multivariate model. However, the hypothesis of constancy of correlation was found not to be supported in various applied contexts. Chang et al. (2010) and Choi and Hammoudeh (2010) applied a symmetric DCC-GARCH model with normally distributed innovations. The present study proposes an asymmetric framework of conditional variance such as not only the magnitude but also the positivity or negativity of innovations determines the conditional variance. Moreover, the present study relaxes the assumption of multivariate normally distributed innovations. We assume multivariate Student-t distributed innovations. The incorporation of a leptokurtic distribution allows modelling the excess leptokurtosis which is not captured by the ARCH process.
} 
period of the study. The main events that took place in the period under consideration are presented in Table 1.

\section{[FIGURE 1 HERE]}

[TABLE 1 HERE]

The main peaks which are observed from Figure 1 are in October 1990, where prices almost doubled within one year. Another peak is observed in September 2000, which was a result of a continuing increase in oil prices since 1999. From 1992 until late 2008 we observe a continuing increase in oil prices, with same disruptions (e.g. during 2007), as well. The prices reached a peak in late 2008. A final peak is observed in June 2009, where prices increased by more than $60 \%$ since the January 2009 price levels.

The main troughs are observed in the early 1999, where prices fell by almost $50 \%$ since 1997, in December 2001, where oil prices fell by $50 \%$ since September 2000 , in January 2007 , where prices fell by almost $40 \%$ compared to the mid-2006 prices, and in early 2009 , where oil prices fell by more than $70 \%$ compared to the June 2008 peak levels.

An important observation that can be made from the above graph is the fact that most of the oil price changes occurred due to precautionary crude oil demand changes. However, there are four aggregate demand-side oil price shocks. One occurred during the Asian economic crisis, the second took place in 2000 , where interest rates decreased significantly and that created a bust in the housing market and construction industries. The third took place in the period 2006-2007, which was a result from the rising demand of oil from China and the fourth demand-side oil price shock took place in the recent global financial crisis of 2008.

\section{Theory and review of the literature}

Economic theory suggests that any asset price should be determined by its expected discounted cash flows (Williams, 1938; Fisher, 1930). Thus, any factor that could alter the 
expected discounted cash flows should have a significant effect on these asset prices. Consequently, any oil price increase would result to increased costs, restraining profits and in greater extend, would cause a decrease in shareholders' value. Hence, any oil price increase should be accompanied by a decrease in the stock prices. Should that effect be the same for oil-importing and oil-exporting countries, though?

Many authors argue that oil price effect on stock markets is an indirect effect and it is fed through the macroeconomic indicators. According to Bjornland (2009) and JimenezRodriguez and Sanchez (2005), an oil price increase is expected to have a positive effect in an oil-exporting country, as the country's income will increase. The consequence of the income increase is expected to be a rise in expenditure and investments, which in turn creates greater productivity and lower unemployment. Stock markets tend to respond positively in such event.

For an oil-importing country, any oil price increase will tend to have the opposite results; see LeBlanc and Chinno (2004) and Hooker (2002). Oil price increase will lead to higher cost of productions, as oil is one of the most important production factors (Arouri and Nguyen, 2010; Backus and Crucini, 2000; Kim and Loungani, 1992). The increase cost will be transferred to the consumers, which will, in turn, lead to lower demand and thus consumer spending, due to higher consumer prices; see for example, Bernanke (2006), Abel and Bernanke (2001), Hamilton (1996), Hamilton (1988a, 1988b) and Barro (1984). Lower consumption could lead to lower production and thus increased unemployment; see Lardic and Mignon (2006), Brown and Yucel (2002) and Davis and Haltiwanger (2001). Stock markets would react negatively in such case; see Sadorsky (1999), and Jones and Kaul (1996).

However, we should not lose sight of the fact that oil price shocks could affect stock markets due to the uncertainty that they create to the financial world, depending on the nature 
of the shock (demand-side or supply-side). In this case stock markets could respond positively to an oil price shock, which originates from the demand side, and negatively if the shock originates from the supply side.

Having briefly discussed the possible transmission mechanisms of an oil price shock to the stock market, we proceed to the analysis of the previous studies in this area.

Mounting evidence suggests a negative relationship between oil prices and stock market returns. Jones and Kaul (1996) were the first to reveal the negative impact of oil price on stock markets, which occurs due to the fact that oil price, is a risk factor for stock markets. Other authors, such as Filis (2010), Chen (2009), Miller and Ratti (2009), Nandha and Faff (2008), O'Neill et al. (2008), Park and Ratti (2008), Driesprong et al. (2008), Ciner (2001) and Gjerde and Sættem (1999) have also provide evidence towards such a negative relationship. Sadorsky (1999) argued that oil price volatility has also an impact on stock returns. Oberndorfer (2009) seconds that opinion in his study on the effect of oil price volatility on European stock markets. A negative relationship between the volatilities of oil price returns and three stock market sectors returns in US (namely, technology, health care and consumer services) was identified by Malik and Ewing (2009). Similar results were obtained by Chiou and Lee (2009). More specifically, Chiou and Lee (2009), using an Autoregressive Conditional Jump Intensity (ARJI) model, found evidence that oil price volatility negatively influence the S\&P500 index. More importantly, their study concluded that periods of increased oil price volatility tend to cause unexpected asymmetric negative effects on S\&P500 returns. Hammoudeh and $\mathrm{Li}$ (2008) provided an interesting finding in this area of concern. They suggested the major events that cause changes in oil prices tend to increase the stock market volatility of the GCC countries. In addition, Arouri and Nguyen (2010) used a two-factor GARCH model to examine the effect of oil prices on European sectors' returns rather than only on aggregate stock market index returns. They concluded 
that oil prices tend to exercise a significant influence on various European sectors (such as, Oil and Gas, Financials, Industrials and Utilities, among others); however, the magnitude and the direction of the effect differ from one sector to another.

Specifically for the oil-exporting countries, Arouri and Rault's (2011) employed a bootstrap panel cointegration technique and a seemingly unrelated regression (SUR) method and provided evidence that positive oil price shocks have positive impact on the stock market performance of GCC countries. Similar results were also documented by Bashar (2006). Hammoudeh and Aleisa (2004), on the other hand, found a bidirectional relationship between oil prices and stock markets, in oil-exporting countries.

Other studies concentrate their interest in the investigation of the oil price shock origin, i.e. demand-side or supply-side shock. These studies include Hamilton (2009a,b), Lescaroux and Mignon (2008), Barsky and Kilian (2004) and Terzian (1985). The origin of an oil price shock is an important component when studying the relationship between oil prices and stock markets. In particular, Lescaroux and Mignon (2008) suggest that supplyside shocks could be related to higher oil price volatility, although it may not be the only reason. Demand-side shocks also justify high oil price volatility. In addition, Hamilton (2009b) argued that demand-side shock deriving from industrialization of countries such as China could have a significant impact. He also voiced the opinion that lack of immediate response of oil-supply to a large scale increase in oil-demand could result to a demand-side shock. Kilian and Park (2009) advocated that demand-side oil price shocks influence stock prices more than the supply-side oil price shocks. Demand-side oil price shocks exercise a negative influence on stock prices due to the precautionary demand for crude oil, which echoes the uncertainty of future oil supply availability. However, they suggested that if the demand-side oil price shock is driven by global economic expansion, then higher oil prices will cause a positive effect on stock prices, which is in line with Hamilton's (2009b) views. 
All that said, a wealth of literature suggests that there is no relationship between oil price and stock markets; see for example Cong et al. (2008), Haung et al. (1996) and Chen et al. (1986). Concerning the oil-exporting countries, Al Janabi, Hatemi and Irandoust (2010) used bootstrap test for causality appropriate for non-normal financial data with time-varying volatility and concluded that GCC stock markets are informationally efficient with regard to oil prices, i.e. oil prices do not tend to affect these stock markets and thus oil prices cannot be used as predictors for the GCC stock markets. Specifically for oil-importing countries, AlFayoumi (2009) found no evidence that oil price shocks affect the stock markets. Other authors suggest that oil prices do not seem to have any effect in the economy after the 1980s (Lescaroux and Mignon, 2008; Nordhaus, 2007; Blanchard and Gali, 2007; Bernanke et al., 1997; Hooker 2002, 1996). Miller and Ratti (2009) concluded that oil price effects are insignificant after 1999 due to oil price bubbles which have taken place since the early 2000 . Jammazi and Aloui (2010) and Apergis and Miller (2009) painted the same picture suggesting that oil prices do not affect stock market performance. Such conclusions could originate from the fact that oil prices are not any more a significant source for economic downturn, as was suggested by Hamilton (1983). Nowadays, the majority of the countries have turned the focus of their monetary policy on inflation stability putting an effort to the absorption of any shocks that could cause inflationary pressures - e.g. oil price shocks (Lescaroux and Mignon, 2008; Blanchard and Gali, 2007; Bernanke et al., 1997). Furthermore, due to increased productivity, investments and renewable energy sources, firms are able to absorb increased production input costs without the need of price increases (International Energy Agency, 2006). Wage flexibility plays an important role on the reduced impact of oil price shocks, as well. Nordhaus (2007) suggested that due to the greater wage flexibility in some countries, responses to oil price shocks tend to be more neoclassical rather than Keynesian. Similar evidence was adduced by Blanchard and Gali (2007). Neoclassical 
theory, in contrast to the Keynesians, argues that effect on output is much smaller and thus oil price shocks should have minimum impact in the economy. Hence, according to this theory, oil price shocks should have small or no impact on stock markets today, as well.

\section{Model and data description}

\subsection{Model description}

It should be mentioned that the present study focuses on investigating the undeviating time-varying correlation between stock market and oil prices. Thus, we do not intend either to estimate a system that isolates oil price shocks or to investigate what other exogenous variables might have changed and which other endogenous variables might have taken the oil price pressure.

In the paragraphs follow, the model framework of our study is presented. Let the $(n \times 1)$ vector $\left\{\mathbf{y}_{t}\right\}$ refer to the multivariate stochastic process to be estimated. In the present model framework, $n=2$ and $\mathbf{y}_{t}=\left(\begin{array}{c}y_{1, t} \\ y_{2, t}\end{array}\right)$, where $y_{1, t}$ denotes the stock index log-returns and $y_{2, t}$ denotes the log-returns of the oil prices (log-returns are first difference of logarithmic prices). The innovation process for the conditional mean $\boldsymbol{\varepsilon}_{t} \equiv \mathbf{y}_{t}-\boldsymbol{\mu}_{t}$ has an $(n \times n)$ conditional covariance matrix $V_{t-1}\left(\mathbf{y}_{t}\right) \equiv \mathbf{H}_{t}$ :

$$
\begin{gathered}
\mathbf{y}_{t}=\boldsymbol{\mu}_{t}+\boldsymbol{\varepsilon}_{t} \\
\boldsymbol{\varepsilon}_{t}=\mathbf{H}_{t}^{1 / 2} \mathbf{z}_{t} \\
\mathbf{z}_{t} \sim f\left(\mathbf{z}_{t} ; \mathbf{0}, \mathbf{I}, v\right) \\
\mathbf{H}_{t}=\sigma\left(\mathbf{H}_{t-1}, \mathbf{H}_{t-2}, \ldots, \boldsymbol{\varepsilon}_{t-1}, \boldsymbol{\varepsilon}_{t-2}, \ldots\right),
\end{gathered}
$$

where $E_{t-1}\left(\mathbf{y}_{t}\right) \equiv \boldsymbol{\mu}_{t}$ denotes the mean of $\mathbf{y}_{t}$ conditional the available information at time $t-1$, $I_{t-1} \cdot \mathbf{z}_{t}$ is an $(n \times 1)$ vector process such that $E\left(\mathbf{z}_{t}\right)=\mathbf{0}$ and $E\left(\mathbf{z}_{t} \mathbf{z}_{t}^{\prime}\right)=\mathbf{I} . f\left(\mathbf{z}_{t} ; \mathbf{0}, \mathbf{I}, v\right)$ denotes the multivariate standardized Student-t density function: 


$$
f\left(\mathbf{z}_{t} ; \mathbf{0}, \mathbf{I}, v\right)=\frac{\Gamma((v+n) / 2)}{\Gamma(v / 2)(\pi(v-2))^{n / 2}}\left(1+\frac{\mathbf{z}_{t}^{\prime} \mathbf{z}_{t}}{v-2}\right)^{-\frac{v+n}{2}}
$$

where $\Gamma($.$) is the gamma function and v$ is the degree of freedoms to be estimated, for $v>2$. The multivariate Student-t distribution was first proposed in the estimation of multivariate ARCH models by Harvey et al. (1992) and Fiorentini et al. (2003). $\sigma($.$) is a positive$ measurable function of the lagged conditional covariance matrices and the innovation process. Student-t distribution allows modelling the excess leptokurtosis which is not captured by the ARCH process ${ }^{4}$.

Engle (2002) introduced the Dynamic Conditional Correlation GARCH, or the DCCGARCH, model. The DCC-GARCH can be successively estimated for large time-varying covariance matrices (moreover, it requires the estimation of less number of parameters than other multivariate GARCH models). It assumes that the covariance matrix can be decomposed such as:

$$
\mathbf{H}_{t}=\boldsymbol{\Sigma}_{t}^{1 / 2} \mathbf{C}_{t} \boldsymbol{\Sigma}_{t}^{1 / 2}
$$

where $\Sigma_{t}^{1 / 2}$ is the diagonal matrix with the conditional standard deviations along the diagonal, i.e.:

$$
\boldsymbol{\Sigma}_{t}^{1 / 2}=\operatorname{diag}\left(\sigma_{1, t}, \sigma_{2, t}, \ldots, \sigma_{n, t}\right),
$$

and $\mathbf{C}_{t}$ is the matrix of conditional correlations. The model is estimated in two steps. At the first step, the conditional variances, $\sigma_{i, t}^{2}$, for the $i=1, \ldots, n$ assets, are estimated as Glosten et al.'s (1993) GJR(1,1) models:

$$
\sigma_{i, t}^{2}=a_{i, 0}+a_{i} \varepsilon_{i, t-1}^{2}+\gamma_{i} d\left(\varepsilon_{i, t-1}<0\right) \varepsilon_{i, t-1}^{2}+b_{i} \sigma_{i, t-1}^{2},
$$

where $a_{i, 0}, a_{i}, \gamma_{i}, b_{i}$ are parameters to be estimated, $d($.$) denotes the indicator function (i.e.$ $d\left(\varepsilon_{t-1}<0\right)=1$ if $\varepsilon_{t-1}<0$, and $d\left(\varepsilon_{t-1}<0\right)=0$ otherwise $)$. The GJR model allows good news,

\footnotetext{
${ }^{4}$ The degree of leptokurtosis induced by the ARCH process does not capture all of the leptokurtosis present in log-returns. Thus, there is a fair amount of evidence that the conditional distribution of $\boldsymbol{\varepsilon}_{t}$ is non-normal. For details, see Xekalaki and Degiannakis (2010).
} 
$\left(\varepsilon_{t-1}>0\right)$, and bad news, $\left(\varepsilon_{t-1}<0\right)$, to have differential effects on the conditional variance (i.e. leverage or asymmetric effect). Therefore, good news has an impact of $a_{i}$, while bad news has an impact of $a_{i}+\gamma_{i}$. In the symmetric GARCH model, the variance only depends on the magnitude and not the sign of $\varepsilon_{t}$, which is somewhat at odds with the empirical behaviour of log-returns, where the leverage effect may be present.

At the second step, using the residuals resulting for the first stage, the conditional correlation is estimated. The time varying correlation matrix has the form:

$$
\mathbf{C}_{t}=\mathbf{Q}_{t}^{*-1 / 2} \mathbf{Q}_{t} \mathbf{Q}_{t}^{*-1 / 2}
$$

The correlation matrix, $\mathbf{Q}_{t}=\left(q_{i, j, t}\right)$, is computed using

$$
\mathbf{Q}_{t}=(1-a-b) \overline{\mathbf{Q}}+a\left(\mathbf{z}_{t-1} \mathbf{z}_{t-1}^{\prime}\right)+b \mathbf{Q}_{t-1},
$$

where $\mathbf{z}_{t}$ are the residuals standardized by their conditional standard deviation, i.e. $\mathbf{z}_{t}=\left(z_{1, t}, z_{2, t}, \ldots, z_{n, t}\right)^{\prime}=\left(\varepsilon_{1, t} \sigma_{1, t}^{-1}, \varepsilon_{2, t} \sigma_{2, t}^{-1}, \ldots, \varepsilon_{n, t} \sigma_{n, t}^{-1}\right)^{\prime}, \overline{\mathbf{Q}}$ is the unconditional covariance of the standardized residuals and $\mathbf{Q}_{t}^{*-1 / 2}$ is a diagonal matrix composed of the square roots of the inverse of the diagonal elements of $\mathbf{Q}_{t}$, i.e. $\mathbf{Q}_{t}^{*-1 / 2}=\operatorname{diag}\left(q_{1,1, t}^{-1 / 2}, q_{2,2, t}^{-1 / 2}, \ldots, q_{n, n, t}^{-1 / 2}\right)$. For technical information about the estimation of the model you are referred to Xekalaki and Degiannakis (2010).

The detailed presentation of DCC-GARCH-GJR model with Student-t distribution for $n=2$ dimensions follows: 


$$
\begin{aligned}
& \left(\begin{array}{l}
y_{1, t} \\
y_{2, t}
\end{array}\right)=\left(\begin{array}{l}
b_{1,0} \\
b_{2,0}
\end{array}\right)+\left(\begin{array}{l}
\varepsilon_{1, t} \\
\varepsilon_{2, t}
\end{array}\right) \\
& \left(\begin{array}{l}
\varepsilon_{1, t} \\
\varepsilon_{2, t}
\end{array}\right)=\mathbf{H}_{t}^{1 / 2}\left(\begin{array}{l}
z_{1, t} \\
z_{2, t}
\end{array}\right) \\
& \left(\begin{array}{l}
z_{1, t} \\
z_{2, t}
\end{array}\right) \sim f\left(\left(\begin{array}{l}
z_{1, t} \\
z_{2, t}
\end{array}\right) ;\left(\begin{array}{l}
0 \\
0
\end{array}\right),\left(\begin{array}{ll}
1 & 0 \\
0 & 1
\end{array}\right), v\right) \\
& f\left(\left(\begin{array}{l}
z_{1, t} \\
z_{2, t}
\end{array}\right) ;\left(\begin{array}{l}
0 \\
0
\end{array}\right),\left(\begin{array}{ll}
1 & 0 \\
0 & 1
\end{array}\right), v\right)=\frac{\Gamma((v+n) / 2)}{\Gamma(v / 2)(\pi(v-2))^{n / 2}}\left(1+\frac{\left(\begin{array}{c}
z_{1, t} \\
z_{2, t}
\end{array}\right)\left(\begin{array}{c}
z_{1, t} \\
z_{2, t}
\end{array}\right)}{v-2}\right)^{-\frac{v+n}{2}} \\
& \mathbf{H}_{t}=\boldsymbol{\Sigma}_{t}^{1 / 2}\left(\begin{array}{cc}
q_{1,1, t}^{-1 / 2} & 0 \\
0 & q_{2,2, t}^{-1 / 2}
\end{array}\right) \mathbf{Q}_{t}\left(\begin{array}{cc}
q_{1,1, t}^{-1 / 2} & 0 \\
0 & q_{2,2, t}^{-1 / 2}
\end{array}\right) \boldsymbol{\Sigma}_{t}^{1 / 2} \\
& \boldsymbol{\Sigma}_{t}^{1 / 2}=\left(\begin{array}{cc}
\sqrt{a_{1,0}+a_{1} \varepsilon_{1, t-1}^{2}+\gamma_{1} d\left(\varepsilon_{1, t-1}<0\right) \varepsilon_{1, t-1}^{2}+b_{1} \sigma_{1, t-1}^{2}} & 0 \\
0 & \sqrt{a_{2,0}+a_{2} \varepsilon_{2, t-1}^{2}+\gamma_{2} d\left(\varepsilon_{2, t-1}<0\right) \varepsilon_{2, t-1}^{2}+b_{2} \sigma_{2, t-1}^{2}}
\end{array}\right), \\
& \mathbf{Q}_{t}=(1-a-b) \overline{\mathbf{Q}}+a\left(\left(\begin{array}{c}
z_{1, t-1} \\
z_{2, t-1}
\end{array}\right)\left(\begin{array}{c}
z_{1, t-1} \\
z_{2, t-1}
\end{array}\right)^{\prime}\right)+b \mathbf{Q}_{t-1}
\end{aligned}
$$

\subsection{Data description}

In this study, we use monthly data for oil prices and stock market indices. The sample consists of three oil-exporting countries (Canada, Mexico and Brazil) and three oil-importing countries (US, Germany and Netherlands). The stock market indices are: S\&P/TSX 60 (Canada), MXICP 35 (Mexico), Bovespa Index (Brazil), Dow Jones Industrial (USA), DAX 30 (Germany) and AEX General Index (Netherlands). To set the sample, the following three criteria should have been satisfied: (i) all countries should have a well established stock market, (ii) the selected countries are in the top 20 oil-importers and oil-exporters, and (iii) the mixture of traditional stock markets and developing stock markets was carefully considered.

US are the largest crude oil importer with imports of 11 billion barrels per day (bpd) in 2008 , which accounted for $63.2 \%$ of the domestic consumption. Germany and Netherlands imported a significantly higher proportion of their domestic consumption. In particular Germany imported in $2008112.8 \%$ of its domestic consumption (or nearly 3 billion bpd). 
Netherlands, on the other hand, imported 2.7 million bpd, which was equal to $100 \%$ of their domestic consumption.

Regarding the oil exporting countries, Canada exported 2.4 million bpd and that is equal to the $3.6 \%$ of the world total crude oil exports. Mexico exported about 1.3 million bpd in 2008, which accounts for the $2.1 \%$ of the world total crude oil exports. Finally, Brazil exported almost half a million bpd in 2008.

The Brent ${ }^{5}$ crude oil index is used as it accounts for the $60 \%$ of the world oil daily production (Maghyereh, 2004). The data range from January 1987 to September 2009. However, for Mexico the data used are from January 1988 to September 2009. All prices from both markets (oil and stock) are expressed in dollar terms and have been extracted from Datastream $^{\circledR}$ Database. The data range is primarily influenced by the data availability. In addition, data from 70s and 80s have been widely used in the literature, while recent data of the above form (from several countries) has not been considered previously and is of great importance due to the recent economic crisis. Still, the sample period includes, apart from the recent economic crisis, other major events such as the first and the second war in Iraq, the Asian economic crisis and the terrorist attack in US, which allow the researchers to generate important conclusion regarding the relationship between oil prices and stock market returns.

The DCC-GARCH-GJR model was estimated for higher sampling frequencies, i.e. weekly and daily sampling frequencies, but the results are qualitatively similar. However, for purposes of illustration the monthly sampling frequency is proposed ${ }^{6}$.

\footnotetext{
${ }^{5}$ WTI oil prices were also considered but the results are qualitatively similar.

${ }^{6}$ Daily prices produce more volatile figures, as expected, although there are specific periods where a peak or a trough in correlation coefficient is clear.
} 


\section{Empirical findings}

\subsection{Oil price and stock market movements}

Figure 2 plots the stock market indices over time. Taking into consideration the peaks and troughs of oil prices (see Section 2) and the events that have taken place during our period of study (see Tables 1 and 2), we can initiate a preliminary discussion on the relationship between oil and stock market prices.

\section{[FIGURE 2 HERE]}

\section{[TABLE 2 HERE]}

Primarily, we observe that stock markets do not always move at the same directions with oil prices. For example, during 1990 oil prices exhibited a peak, whereas the majority of the stock markets showed a stable performance, if not a declining one. In addition, during 1997-1998 an oil price decrease is observed, whereas the majority of the stock markets were exhibiting an increase in their index levels. Furthermore during the period 1999-2000, when we observe another period of oil price increases (reaching a peak in late 2000), stock market prices showed an increase, as well. Stock market showed a decreasing pattern during the period 2000-2003. For the first half of this period, oil prices suffered a decrease, as well. However, for the second half of the 2000-2003 period oil prices were increasing constantly. In addition, the period 2004 until mid-2006 is characterised mainly by a continuous oil price increase, as well as, increased stock market prices. During mid-2006 until early 2007, when an oil price trough is observed, stock markets also exhibited a decrease in their price levels. Moreover, during 2007 until mid-2008 and during early 2009 until September 2009, both oil prices and stock market are bullish. Finally, during the period mid-2008 and early 2009, both oil and stock market prices experienced a bearish performance.

The visual inspection of the Figures does not provide a clear distinction between stock market performance and oil prices on oil-importing and oil-exporting countries. 
We should not lose sight of the fact that the above analysis is only preliminary. The actual conclusions for the dynamic correlation between oil prices and stock market performance should be based on the analysis of the DCC-GARCH-GJR model presented in the following section. The dynamic correlation findings will describe more explicitly the comovements between oil prices and stock market indices.

\subsection{Dynamic correlation findings}

\subsubsection{Contemporaneous correlations}

The graphs resulted from the time-varying correlation coefficients as computed from equation (8) between each stock market index and the Crude oil prices are presented in Figure $3 .^{7}$

\section{[FIGURE 3 HERE]}

During the period 1990-1991, we observe that all stock markets, apart from the Brazilian one, show a considerable negative correlation with oil prices. This is the period dominated by changes in the precautionary demand for crude oil, a period when Iraq invaded Kuwait and, in turn, US invaded Iraq. In addition, it is a period when the Soviet Union collapses. Although this oil crisis was considered as a mild one, the effects were significant, as, according to Taylor (1993), the reaction by the government regulations were not in a flexible manner.

Furthermore, the Asian economic crisis, which took place in mid-1997 and early 1998, did not produce any significant positive or negative correlation between oil prices and stock markets, for most of the markets under consideration. All stock markets, apart from US, exhibited a low positive correlation with oil prices, during the Asian Crisis. Exemption was

\footnotetext{
${ }^{7}$ The estimated parameters are not reported, but they are available upon request. Moreover, the specification tests of the models, i.e. ARCH-LM test, autocorrelation tests of the standardized residuals, etc., which provide the adequacy of the DCC-GARCH-GJR model, are also available. The models were estimated in G@RCH 5.0 package for Ox Metrics ${ }^{\circledR}$; for technical details about the estimation of the models see Laurent (2007).
} 
the German stock market, which showed a moderate positive correlation during this period. The Asian economic crisis created a negative aggregate demand-side oil price shock, driving oil prices at lower levels. The majority of stock markets in that period were also experienced a small decline or a stable performance.

Continuing along the time-line of events, we observe that for a period of six years, following the Asian economic crisis, i.e. 1998-2004, all stock market from oil-exporting countries and the Netherlands stock market exhibit a positive correlation with oil prices (apart for the mid-2003, where correlation became weakly negative). During this period we have several oil production cuts by OPEC (especially in the period 1998-1999), decisions for oil production increases (mainly in 2000 due to the rapid growth of the housing market) and the PdVSA workers' strike that took place in Venezuela (in 2002). In addition, we experienced the September 2001 terrorist attack in the World Trade Centre (WTC) in US. The German and the US stock markets had a positive correlation with oil prices at the period of the 9/11 and during 2000, as well.

However, during the period 1998-2004, we had another major event that caused turbulence in oil and stock prices. That was the second war in Iraq, which started in March 2003. During the second invasion of US troops in Iraq, all stock markets, apart from the Mexican market, were exhibiting a negative correlation with oil prices, although weak. During the second war in Iraq, oil prices increase significantly but at the same time it caused world stock markets to react negatively.

Inside the period 1998-2004, a peak in correlation coefficient is observed around the year 2000 for all countries. This high positive correlation between oil and stock market prices was initiated because of the high demand for oil due to the rapid increase in the housing market and construction industry, which was a result of decreasing interest rates worldwide. 
The next period of interest, is the period 2006 until mid 2008 which is characterised as a period when oil prices increased significantly due to rising demand, mainly by China. The correlation coefficient showed an increasing and positive pattern for all countries. This aggregate demand-side oil price shock was expected to have a positive effect on stock markets (both in oil-importing and oil-exporting countries) as it signals an increase in world trade (mainly dominated by China). This finding is in line with Hamilton (2009b) and Kilian and Park (2009) findings, who suggested that aggregate demand-side oil price shocks, originated by world economic growth, have a positive impact on stock prices.

During the mid-2008 and early 2009 the pattern shows that correlation coefficient for all stock markets is still in the positive area. The main event at this period is the global financial crisis initiated from the export of US toxic mortgages to the rest of the world, as asset-backed securities (Stiglitz, 2009), which can be regarded as an aggregate demand-side oil price shock (International Energy Agency, 2009). The positive correlation between oil and stock market prices can be explained by the fact that such crisis caused stock markets to enter bearish territories and caused oil prices to decline heavily, as well.

We should make clear though that there are only three periods of noteworthy positive or negative correlation between oil prices and stock markets. These are the periods 19901991 (precautionary demand oil price shock - negative correlation), early 2000 until mid2000 (aggregate demand-side oil price shocks - positive correlation) and 2007-2008 (aggregate demand-side oil price shock - positive correlation).

In addition, there is not a period where some differences in the correlation between oil and stock market prices for oil-importing and oil-exporting countries could be observed. The explanation of such finding lies to the events that took place and caused changes in oil and stock market prices. 
The first war in Iraq and the collapse of the Soviet Union caused a significant turbulence and uncertainty in world markets, regardless the status of the stock market (oilimporting or oil-exporting). Furthermore, the Asian economic crisis caused a significant decrease in oil demand and at the same time uncertainty in all world stock markets. In addition, the boom that the housing market experienced in 2000 created a positive environment for world markets and at the same time a high demand for oil, driving the prices of both markets in higher levels. The 9/11 terrorist attack and the second war in Iraq also created significant uncertainty in all economies, causing similar movements in their stock markets and thus similar correlation with oil prices (i.e. negative). In addition, the Chinese growth and its impact in the world trade caused euphoria in all stock markets regardless the country of origin. Similarly, the last world financial crisis influenced all stock market similarly and thus their correlation with oil prices was similar.

Thus, two main findings can be extracted from our analysis. Oil price shocks in periods of world turmoil or during fluctuations of the global business cycle (downturn or expansion) seem to have a significant impact on the relationship between oil and stock market prices, regardless the status of the market (i.e. belonging to an oil-importing or oilexporting country). However, all other oil price shocks originated by OPEC's productions cuts, hurricanes etc., do not seem to have a significant impact on the correlation between oil and stock markets. Moreover, important precautionary demand side oil price shocks (i.e. first and second war in Iraq, 9/11 terrorist attack) tend to cause a negative correlation between oil and stock markets, whereas aggregate demand-side oil price shocks (Asian crisis, Housing market boom, Chinese economic growth, and the latest global financial crisis) cause a significant positive correlation between stock market prices and oil prices. This finding is partly in line with the evidence provided by Hamilton (2009b) and Kilian and Park (2009). 
Overall, the origin of the shock seems to be an important determinant of the correlation magnitude between oil prices and stock markets, as long as the oil shocks originate from major events of world turmoil, such as wars or changes in the phase of the global business cycle. Supply-side shocks do not affect the relationship between stock markets and oil prices. A summary of the findings is provided in Table 3.

\section{[TABLE 3 HERE]}

The magnitude of the correlation is another issue of interest. Overall, evidence suggests that the origin of the shock does not have an impact on the magnitude of the correlation. On the contrary, the main determinant of the correlation magnitude is the event that caused changes in oil and stock market prices. Thus, the aggregate demand-side shocks experienced in 1997-1998 and 2007-2008 and the precautionary demand shock experienced in 1990-1991 generated higher correlation coefficients, in absolute terms, than any other supply-side, demand-side or precautionary demand shocks documented earlier.

\subsubsection{Lagged correlations}

Market participants, mainly, are interested in exploiting the ability of one market to provide information for the future movement of another market. In the previous section, the contemporaneous correlation between the oil price and the stock price was investigated. In the present paragraph, we seek to investigate whether the lagged movements to energy market interact to shocks to asset market.

Therefore, the vector of the dependent variable is denoted as $\mathbf{y}_{t}=\left(\begin{array}{c}y_{1, t} \\ y_{2, t-1}\end{array}\right) \cdot{ }^{8}$ In other words, the time varying correlation between asset market log-returns of current month and energy market log-returns of previous month is explored. Findings of the lagged time-varying

\footnotetext{
${ }^{8}$ The model framework, presented in equation (8), remains the same.
} 
correlation show that in almost all events under consideration (i.e. the Iraq invasion in Kuwait, the first war in Iraq, the collapse of the Soviet Union, the Asian economic crisis, the housing boom, the 9/11 terrorist attack, the second war in Iraq and the Chinese economic growth), the correlation between the lagged oil prices and current stock prices is negative for all countries, regardless their status (i.e. oil-importing or oil-exporting). The only event that exhibits a positive correlation is the latest global financial crisis in 2008 (see Figure 4). These findings signify the importance of oil prices as risk factor for stock markets.

\section{[FIGURE 4 HERE]}

Magnitude-wise it is evident that the major precautionary demand shocks and the aggregate demand-side shocks generate the highest correlation figure (in absolute terms). Supply-side shocks do not seem to influence the correlation between the lagged oil prices and the current stock prices. This finding is in line with the conclusions that were generated in the contemporaneous correlations section.

[TABLE 4 HERE]

\section{Conclusion}

The paper investigates the time-varying correlation between stock market prices and oil prices for oil-importing and oil-exporting countries considering the origin of oil price shocks (i.e. aggregate demand-side, precautionary demand or supply-side). The dataset consists of monthly stock and oil prices from three oil-exporting countries (Canada, Mexico and Brazil) and three oil-importing countries (US, Germany and Netherlands), from 1987 to 2009.

The conditional correlation is estimated following Engle's (2002) DCC-GARCH model, where the conditional variances are estimated with Glosten's et al. (1993) GJR model. 
The study provides evidence that time-varying correlation of oil and stock prices do not differ for oil-importing and oil-exporting economies. This can be explained by two facts. Firstly, aggregate demand side oil price shocks due to the fact that are caused by fluctuations in the global business cycle are expected to influence all stock markets in the same fashion. The finding that the precautionary demand side oil price shocks tend to influence oilimporting and oil-exporting countries in the same way can be attributed to the fact that the oil sector in the examined oil-importing countries is rather small that the effects of the uncertainty of any future crude oil supply shortages, considering the future crude oil demand, are bare minimum.

However, the correlation changes in respond to the origin of the oil price shocks in periods of world turmoil or changes in the phase of the global business cycle. In particular, precautionary demand shocks, which were caused by wars or terrorist attacks and aggregate demand-side shocks caused by fluctuations of the world business cycle (i.e. Asian crisis, housing market boom, Chinese growth, global financial crisis) tend to be influencing the correlation between oil and stock market prices in much greater extent compared to supplyside shocks originated by OPEC's productions cuts, hurricanes etc.

Moreover, the correlation between asset market log-returns of current month and energy market log-returns of previous month show that oil prices act as a risk factor for the stock markets, as in all events, but the global financial crisis of 2008, the correlation between the lagged oil prices and current stock prices is negative for all stock markets.

Given the current economic and financial environment investors evaluate their alternatives in an effort to diversify their stock market portfolios using other financial instruments or other investment assets. The findings of this paper suggest that during such economic turbulence the oil market cannot represent a safe haven that protects investors from their potential losses in their stock market portfolios. Thus, any attempt to diversify stock 
market risk using the oil market will not produce the desirable outcome for investors. Potentially, investors will have to direct themselves to other commodities.

Our findings partially agree with the findings of other researchers, such as these by Miller and Ratti (2009), Lescaroux and Mignon (2008), Nordhaus (2007), Blanchard and Gali (2007), Bernanke et al. (1997), etc. These past researches concluded that for more than a decade now, oil prices do not affect stock prices.

We summarise the findings as follows: non-economic crises trigger a stronger negative link between oil prices and stock markets and on the other hand, economic crises or booms trigger a stronger positive link between oil prices and stock markets. Hence, precautionary demand shocks are causing negative correlation between oil and stock market prices, whereas aggregate demand-side shocks are causing a positive relationship. Supplyside shocks do not influence the relationship between oil and stock prices. Lagged oil prices act as a risk factor for the stock markets.

For further research, the time-varying correlation between oil prices and stock markets, taking into consideration macroeconomic variables as exogenous variables in the DCC-GARCH framework, is left. Such model will be able to capture any other exogenous variables that might have interacted with oil and stock market prices.

Finally, it would be interesting to provide confidence bands for the time varying correlations, by using bootstrap or Monte Carlo simulations.

\section{Acknowledgement}

Dr. Christos Floros and Dr. Stavros Degiannakis acknowledge the support from the European Community's Seventh Framework Programme (FP7-PEOPLE-IEF) funded under grant agreement no. PIEF-GA-2009-237022. The authors would like to thank Jonathan Batten, the editor in chief of the International Review of Financial Analysis. The helpful 
comments of the referees are gratefully acknowledged. It paved the way for significant improvement of our manuscript. Any remaining errors are our own.

\section{References}

Abel, B.A., \& Bernanke, B.S. (2001). Macroeconomics, Addison Wesley Longman Inc.

Al-Fayoumi, A.N. (2009). Oil prices and stock market returns in oil importing countries: The case of Turkey, Tunisia and Jordan. European Journal of Economics, Finance and Administrative Sciences, 16, 86-101.

Al Janabi, M.A.M., Hatemi-J, A., \& Irandoust, M. (2010). An empirical investigation of the informational efficiency of the GCC equity markets: Evidence from bootstrap simulation. International Review of Financial Analysis, 19, 47-54.

Aloui, C., \& Jammazi, R. (2009). The effects of crude oil shocks on stock market shifts behaviour: A regime switching approach. Energy Economics, 31, 789-799.

Apergis, N., \& Miller, S.M. (2009). Do structural oil - market shocks affect stock prices? Energy Economics, 31(4), 569-575.

Arouri, M.E.H., \& Khuong, N.D. (2010). Oil prices, stock markets and portfolio investment: Evidence from sector analysis in Europe over the last decade. Energy Policy, 38(8), $4528-4539$.

Arouri, M.E.H., \& Nguyen, D.K. (2010). Oil prices, stock markets and portfolio investment: Evidence from sector analysis in Europe over the last decade. Energy Policy, 38, 45284539.

Arouri, M.E.H., \& Rault, C. (2011). Oil prices and stock markets in GCC countries: Empirical evidence from panel analysis. International Journal of Finance and Economics, forthcoming. 
Backus, K.D., \& Crucini, M.J. (2000). Oil prices and the terms of trade. Journal of International Economics, 50, 185-213.

Barro, J.R. (1984). Macroeconomics, Wiley, New York.

Barsky, R., \& Kilian, L. (2004). Oil and the macroeconomy since the 1970s. Journal of Economic Perspectives, 18, 115-134.

Bashar, A.Z. (2006). Wild oil prices, but brave stock markets! The case of GCC stock markets. Operational Research, 6(2), 145-162.

Bernanke, S.B., Gertler, M., \& Watson, M. (1997). Systematic monetary policy and the effects of oil price shocks. Brookings Papers on Economic Activity, 1, 91-148.

Bernanke, S.B. (2006). The economic outlook. Remarks before the National Italian American Foundation, New York, November 28.

Berument, M.H., Ceylan, N.B., \& Dogan, N. (2010). The impact of oil price shocks on the economic growth of selected MENA1 countries. Energy Journal, 31(1), 149-176.

Bharn, R., \& Nikolovann, B. (2010). Global oil prices, oil industry and equity returns: Russian experience. Scottish Journal of Political Economy, 57(2), 169-186.

Bjornland, C.H. (2009). Oil price shocks and stock market booms in an oil exporting country. Scottish Journal of Political Economy, 2(5), 232-254.

Blanchard, J.O., \& Gali, J. (2007). The macroeconomic effects of oil price shocks. Why are the 2000s so different than the 1970s? National Bureau of Economic Research, Working Paper 13368.

Brown, P.A.S., \& Yücel, M.K. (2002). Energy prices and aggregate economic activity: An interpretative survey. Quarterly Review of Economics and Finance, 42, 193-208.

Burbridge, J., \& Harrison, A. (1984). Testing for the effects of oil-price rises using vector autoregressions. International Economic Review, 25(1), 459-484. 
Chang, C-L., McAleer, M., \& Tansuchat, R. (2010). Conditional correlations and volatility spillovers between crude oil and stock index returns. Kyoto Institute of Economic Research, KIER Discussion Paper Series, Discussion Paper, 715.

Chen, N.F., Roll, R., \& Ross, S.A. (1986). Economic forces and the stock market. Journal of Business, 59, 383-403.

Chen, S.S. (2009). Do higher oil prices push the stock market into bear territory? Energy Economics, 32(2), 490-495.

Chiou, J-S., \& Lee, Y-H. (2009). Jump dynamics and volatility: Oil and the stock markets. Energy, 34, 788-796.

Choi, K., \& Hammoudeh, S. (2010). Volatility behavior of oil, industrial commodity and stock markets in a regime-switching environment. Energy Policy, 38, 4388-4399.

Cifarelli, G., \& Paladino, G. (2010). Oil price dynamics and speculation: A multivariate financial approach. Energy Economics, 32, 363-372.

Ciner, C. (2001). Energy shocks and financial markets: Nonlinear linkages. Studies in Nonlinear Dynamics and Econometrics, 5, 203-212.

Cong, R.G., Wei, Y.M., Jiao, J.L., \& Fan, Y. (2008). Relationships between oil price shocks and stock market: An empirical analysis from China. Energy Policy, 36, 3544-3553.

Davis, J.S., \& Haltiwanger, J. (2001). Sectoral job creation and destruction responses to oil price changes. Journal of Monetary Economics, 48, 645-512.

Doğrul, H.G., \& Soytas, U. (2010). Relationship between oil prices, interest rate, and unemployment: Evidence from an emerging market. Energy Economics, 32, 15231528

Driesprong, G., Jacobsen, B., \& Maat, B. (2008). Striking oil: Another puzzle? Journal of Financial Economics, 89(2), 307-327. 
Du, L., He, Y., \& Wei, C. (2010). The relationship between oil price shocks and China's macro-economy: An empirical analysis. Energy Policy, 38, 4142-4151.

Engle, F.R. (2002). Dynamic conditional correlation: A simple class of multivariate GARCH models. Journal of Business and Economic Statistics, 20, 339-350.

Ewing, T.B., \& Thompson, M.A. (2007). Dynamic cyclical comovements of oil prices with industrial production, consumer prices, unemployment and stock prices. Energy Policy, $35,5535-5540$.

Ferderer, J.P. (1996). Oil price volatility and the macroeconomy. Journal of Macroeconomics, 18(1), 1-26.

Filis, G. (2010). Macro economy, stock market and oil prices: Do meaningful relationships exist among their cyclical fluctuations? Energy Economics, 32(4), 877-886.

Fiorentini, G., Sentana, E., \& Calzolari, G. (2003). Maximum likelihood estimation and inference in multivariate conditionally heteroskedastic dynamic regression models with student t innovations. Journal of Business and Economic Statistics, 21, 532-546.

Fisher, I. (1930). The theory of interest, Macmillan, New York.

Gisser, M., \& Goodwin, T.H. (1986). Crude oil and the macroeconomy: Tests of some popular notions. Journal of Money, Credit and Banking, 18(1), 95-103.

Gjerde, O., \& Sættem, F. (1999). Causal relations among stock returns and macroeconomic variables in a small, open economy. Journal of International Financial Markets, Institutions and Money, 9, 61-74.

Glosten, L., Jagannathan, R., \& Runkle, D. (1993). On the relation between the expected value and the volatility of the nominal excess return on stocks. Journal of Finance, 48 , $1779-1801$.

Hamilton, D.J. (1983). Oil and the macroeconomy since World War II. The Journal of Political Economy, 9, 228-248. 
Hamilton, D.J. (1988a). A neoclassical model of unemployment and the business cycle. Journal of Political Economy, 96, 593-617.

Hamilton, D.J. (1988b). Are the macroeconomic effects of oil-price changes symmetric? A comment. Carnegie-Rochester Conference Series on Public Policy, 28, 369-378.

Hamilton, D.J. (1996). This is what happened to the oil price-macroeconomy relationship. Journal of Monetary Economics, 38, 215-220.

Hamilton, D.J. (2009a). Understanding crude oil prices. Energy Journal, 30(2), 179-206.

Hamilton, D.J. (2009b). Causes and consequences of the oil shock of 2007-08. Brookings Papers on Economic Activity, Spring 2009, 215-261.

Hamilton, J.D., \& Herrera, A. M. (2004). Oil shocks and aggregate macroeconomic behavior: the role of monetary policy. Journal of Money, Credit and Banking, 36, 265-286.

Hammoudeh, S., \& Aleisa, E. (2004). Dynamic relationship among GCC stock markets and NYMEX oil futures. Contemporary Economic Policy, 22, 250-269.

Hammoudeh, S., Bhar, R., \& Thompson, M.A. (2010). Re-examining the dynamic causal oilmacroeconomy relationship. International Review of Financial Analysis, 19, 298-305.

Hammoudeh, S., \& Li, H. (2008). Sudden changes in volatility in emerging markets: The case of Gulf Arab stock markets. International Review of Financial Analysis, 17, 4763.

Harvey, C.A., Ruiz, E., \& Sentana, E. (1992). Unobserved component time series models with ARCH disturbances. Journal of Econometrics, 52, 129-157.

Haung, D.R., Masulis, R.W., \& Stoll, H. (1996). Energy shocks and financial markets. Journal of Futures Markets, 16(1), 1-27.

Hondroyiannis, G., \& Papapetrou, E. (2001). Macroeconomic influences on the stock market. Journal of Economics and Finance, 25(1), 33-49. 
Hooker, A.M. (1996). What happened to the oil price-macroeconomy relationship? Journal of Monetary Economics, 38, 195-213

Hooker, A.M. (2002). Are oil shocks inflationary? Asymmetric and nonlinear specifications versus changes in regime. Journal of Money, Credit and Banking, 34(2), 540-561.

Huntington, G.H. (2007). Oil shocks and real U.S. income. Energy Journal, 28(4), 31-46.

International Energy Agency. (2006). World energy outlook.

International Energy Agency. (2009). The impact of the financial and economic crisis on global energy investment. IEA background paper for the G8 energy ministers' meeting 24-25 May 2009.

Jammazi, R., \& Aloui, C. (2010). Wavelet decomposition and regime shifts: Assessing the effects of crude oil shocks on stock market returns. Energy Policy, 38(3), 1415-1435.

Jones, M.C., \& Kaul, G. (1996). Oil and stock markets. Journal of Finance, 51(2), 463-491.

Jimenez-Rodriguez, R. (2009). Oil price shocks and real GDP growth: Testing for nonlinearity. Energy Journal, 30(1), 1-24.

Jimenez-Rodriguez, R., \& Sanchez, M. (2005). Oil price shocks and real GDP growth: Empirical evidence for some OECD countries. Applied Economics, 37(2), 201-228.

Jones, W.D., Leiby, P.N., \& Paik, I.K. (2004). Oil price shocks and the macroeconomy: What has been learned since 1996. Energy Journal, 25(2), 1-32.

Kilian, L. (2008). Exogenous oil supply shocks: How big are they and how much do they matter for the U.S. economy? Review of Economics and Statistics, 90, 216-240.

Kilian, L. (2009). Not all oil price shocks are alike: Disentangling demand and supply shocks in the crude oil market. American Economic Review, 99(3), 1053-1069.

Kilian, L., \& Park, C. (2009). The impact of oil price shocks on the U.S. stock market. International Economic Review, 50, 1267-1287. 
Kim, I.M., \& Loungani, P. (1992). The role of energy in real business cycle models. Journal of Monetary Economics, 29, 173-189.

Korhonen, I., \& Ledyaeva, S. (2010). Trade linkages and macroeconomic effects of the price of oil. Energy Economics, 32, 848-856.

Lardic, S., \& Mignon, V. (2006). Oil prices and economic activity: An asymmetric cointegration approach. Energy Economics, 34, 3910-3915.

Laurent, S. (2007). Estimating and forecasting ARCH models using G@RCH 5, Timberlake Consultants Press, London.

LeBlanc, M., \& Chinn, D.M. (2004). Do high oil prices presage inflation? The evidence from G5 countries. Business Economics, 34, 38-48.

Lee, K., Ni, S., \& Ratti, R.A. (1995). Oil shocks and the macroeconomy: The role of price variability. Energy Journal, 16(4), 39-56.

Lee, Y-H., \& Chiou, J-S. (2011). Oil sensitivity and its asymmetric impact on the stock market. Energy, 36, 168-174.

Lescaroux, F., \& Mignon, V. (2008). On the influence of oil prices on economic activity and other macroeconomic and financial variables. OPEC Energy Review, 32(4), 343-380.

Maghyereh, A. (2004). Oil price shocks and emerging stock markets. A generalized VAR approach. International Journal of Applied Econometrics and Quantitative Studies, $1(2), 27-40$.

Malik, F., \& Ewing, B. (2009). Volatility transmission between oil prices and equity sector returns. International Review of Financial Analysis, 18(3), 95-100.

Miller, J.I., \& Ratti, R.A. (2009). Crude oil and stock markets: Stability, instability, and bubbles. Energy Economics, 31(4), 559-568.

Mork, A.K., Olsen, O., \& Mysen, H.T. (1994). Macroeconomic responses to oil price increases and decreases in seven OECD countries. Energy Journal, 15(4), 19-35. 
Nandha, M., \& Faff, R. (2008). Does oil move equity prices? A global view. Energy Economics, 30, 986-997.

Nordhaus, W. (2007). Who's afraid of a big bad oil shock? Brookings Papers on Economic Activity, 2, 219-240.

Oberndorfer, U. (2009). Energy prices, volatility, and the stock market: Evidence from the Eurozone. Energy Policy, 37(12), 5787-5795.

O'Neill, J.T., Penm, J., \& Terrell, D.R. (2008). The role of higher oil prices: A case of major developed countries. Research in Finance, 24, 287-299.

Papapetrou, E. (2001). Oil price shocks, stock market, economic activity and employment in Greece. Energy Economics, 23(5), 511-532.

Park, J., \& Ratti, R.A. (2008). Oil prices and stock markets in the U.S. and 13 European countries. Energy Economics, 30, 2587-2608.

Sadorsky, P. (1999). Oil price shocks and stock market activity. Energy Economics, 21, 449469.

Stiglitz, J. (2009). The current economic crisis and lessons for economic theory. Eastern Economic Journal, 35, 281-296.

Taylor, B.J. (1993). Discretion versus policy rules in practice. Carnegie-Rochester Conference Series on Public Policy, 39, 195-214.

Terzian, P. (1985). OPEC The insider story, Zed Books, London.

Williams, B.J. (1938). The theory of investment value, Harvard University Press, Cambridge. Xekalaki, E., \& Degiannakis, S. (2010). ARCH models for financial applications, Wiley, New York. 
Figures

FIGURE 1. Brent crude oil price, in dollars, from January 1987 to September 2009.

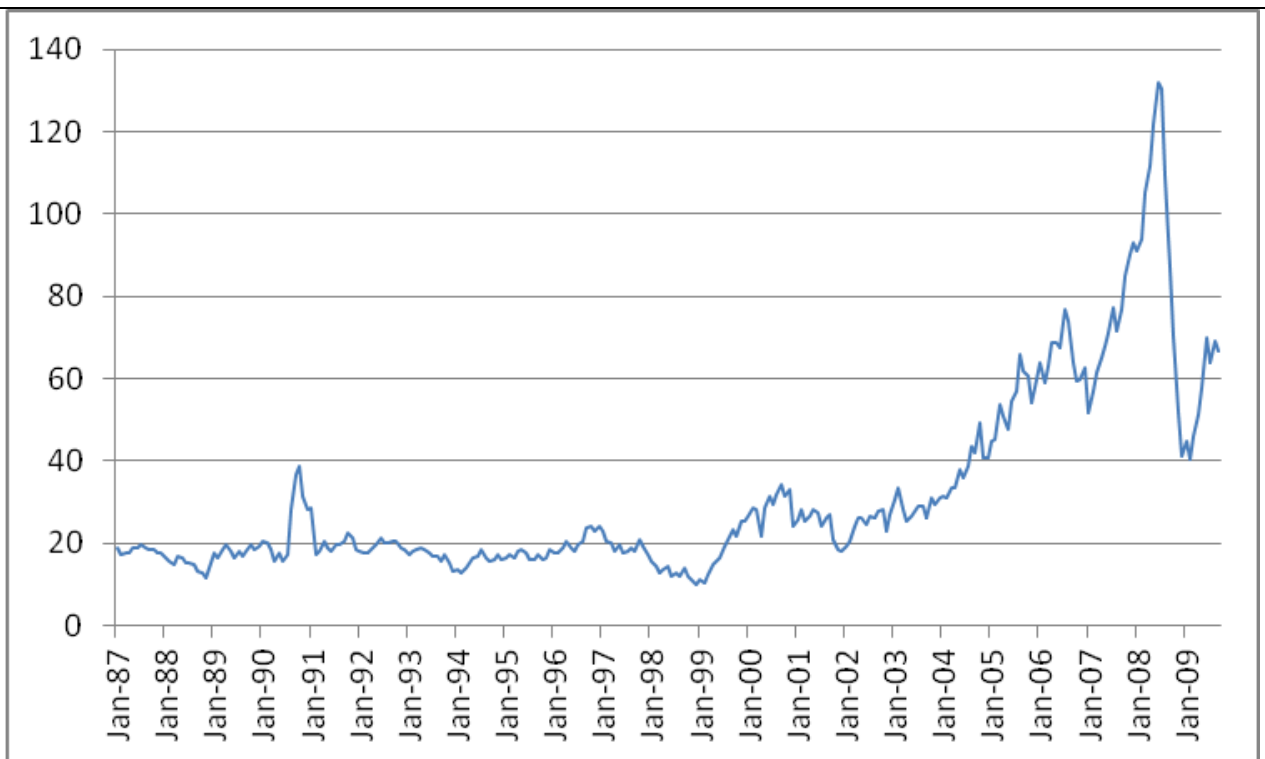




\section{FIGURE 2: Stock Market Indices.}

\section{a) Oil Exporting Countries}

\section{Canada: S\&P/TSX 60 Index}

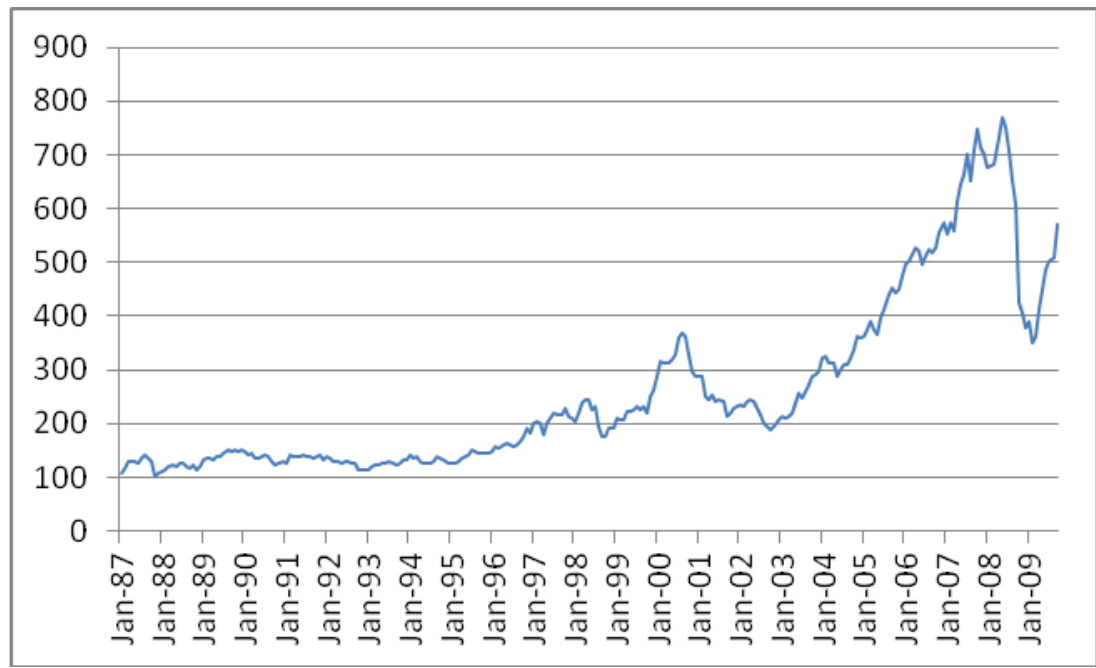

\section{Mexico: MXIPC 35 Index}

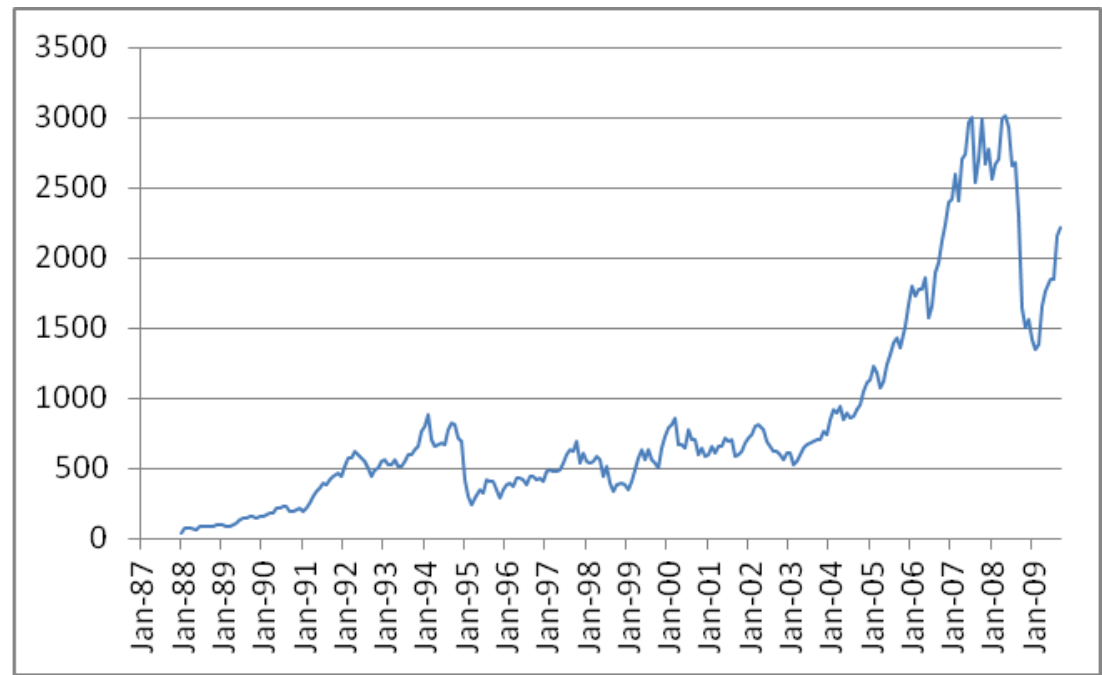

\section{Brazil: Bovespa Index}

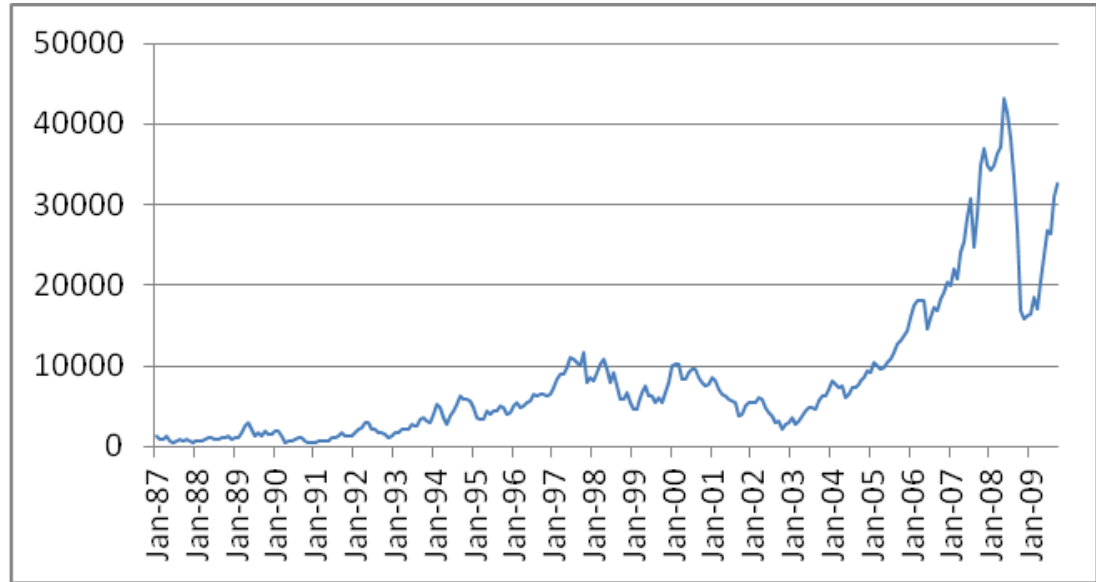




\section{b) Oil Importing Countries}

\section{USA: Dow Jones Industrial Index}

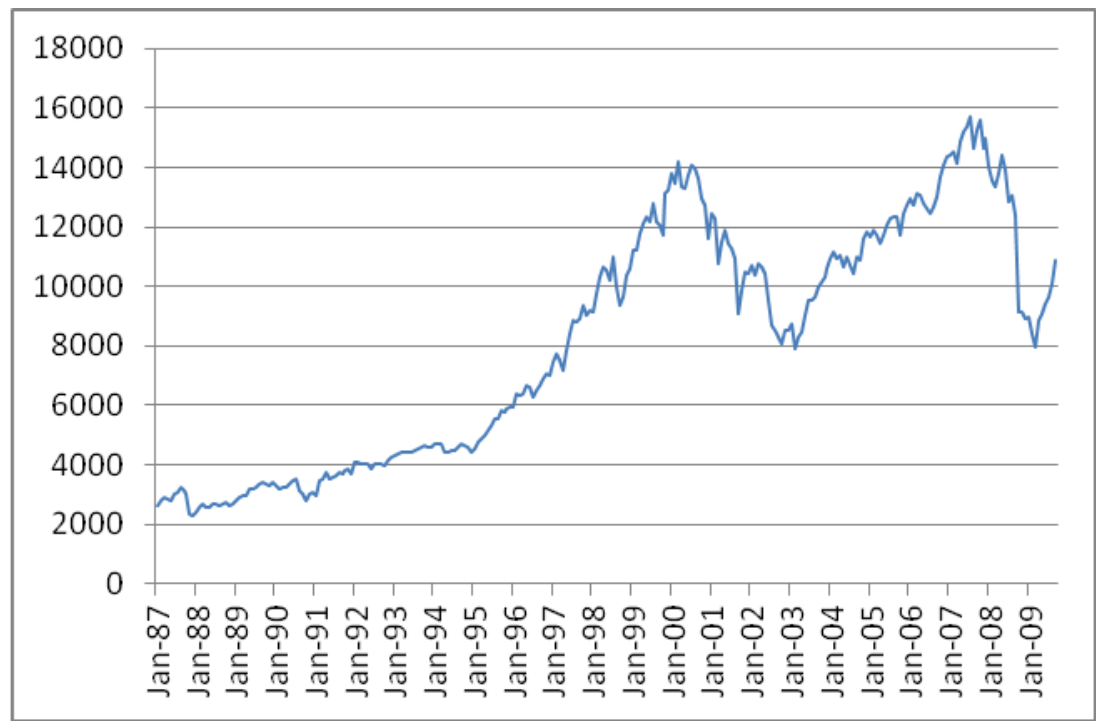

\section{Germany: DAX 30 Index}

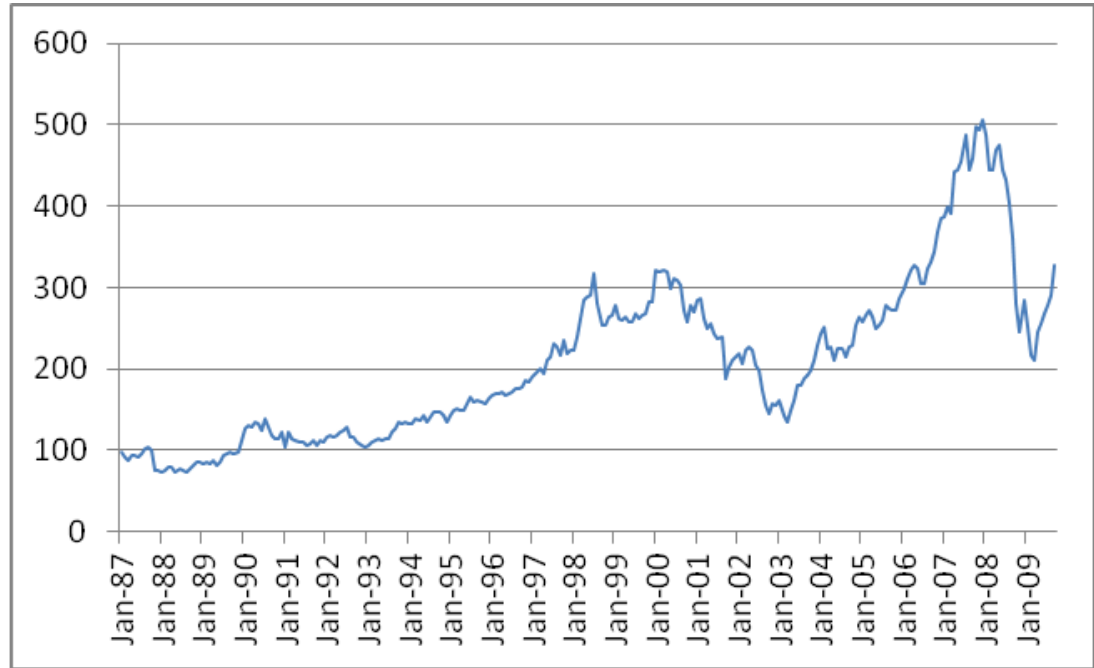

\section{Netherlands: AEX General Index}

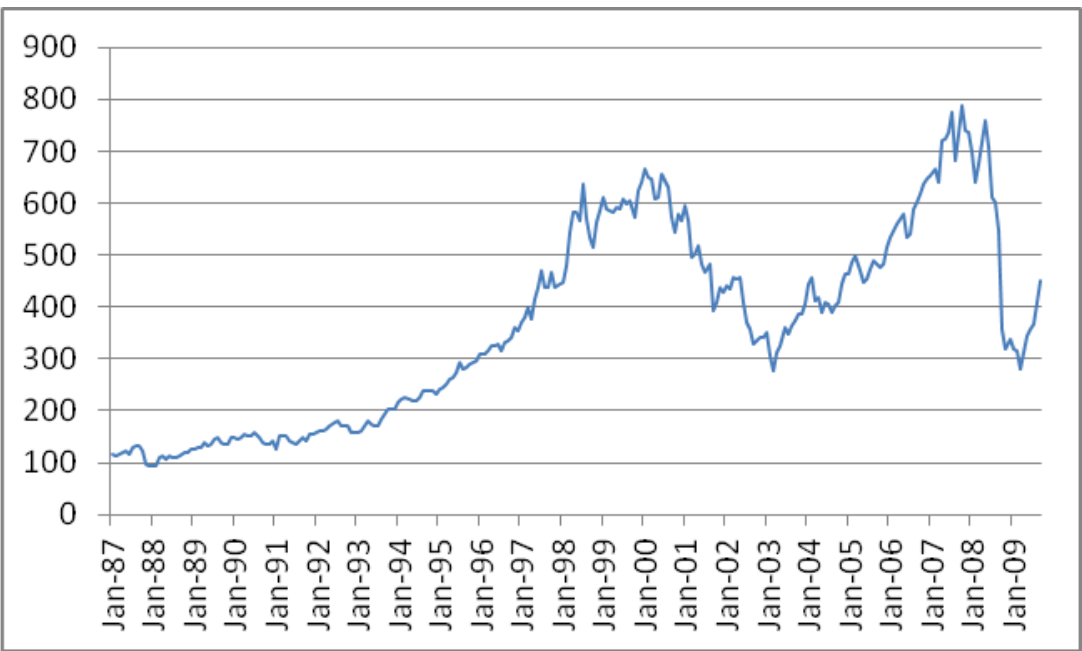


FIGURE 3: Dynamic Correlation between stock market index and the Crude oil price computed from the DCC-GARCH model with Student-t distribution as:

$$
\begin{gathered}
\mathbf{C}_{t}=\mathbf{Q}_{t}^{*-1 / 2} \mathbf{Q}_{t} \mathbf{Q}_{t}^{*-1 / 2}, \text { where } \\
\mathbf{Q}_{t}^{*-1 / 2}=\left(\begin{array}{cc}
q_{1,1, t}^{-1 / 2} & 0 \\
0 & q_{2,2, t}^{-1 / 2}
\end{array}\right) \\
\mathbf{Q}_{t}=(1-a-b) \overline{\mathbf{Q}}+a\left(\left(\begin{array}{c}
z_{1, t-1} \\
z_{2, t-1}
\end{array}\right)\left(\begin{array}{c}
z_{1, t-1} \\
z_{2, t-1}
\end{array}\right)^{\prime}\right)+b \mathbf{Q}_{t-1}
\end{gathered}
$$

\section{a) Oil Exporting Countries}

Time varying correlation between Brazilian stock market index (Bovespa) and crude oil.

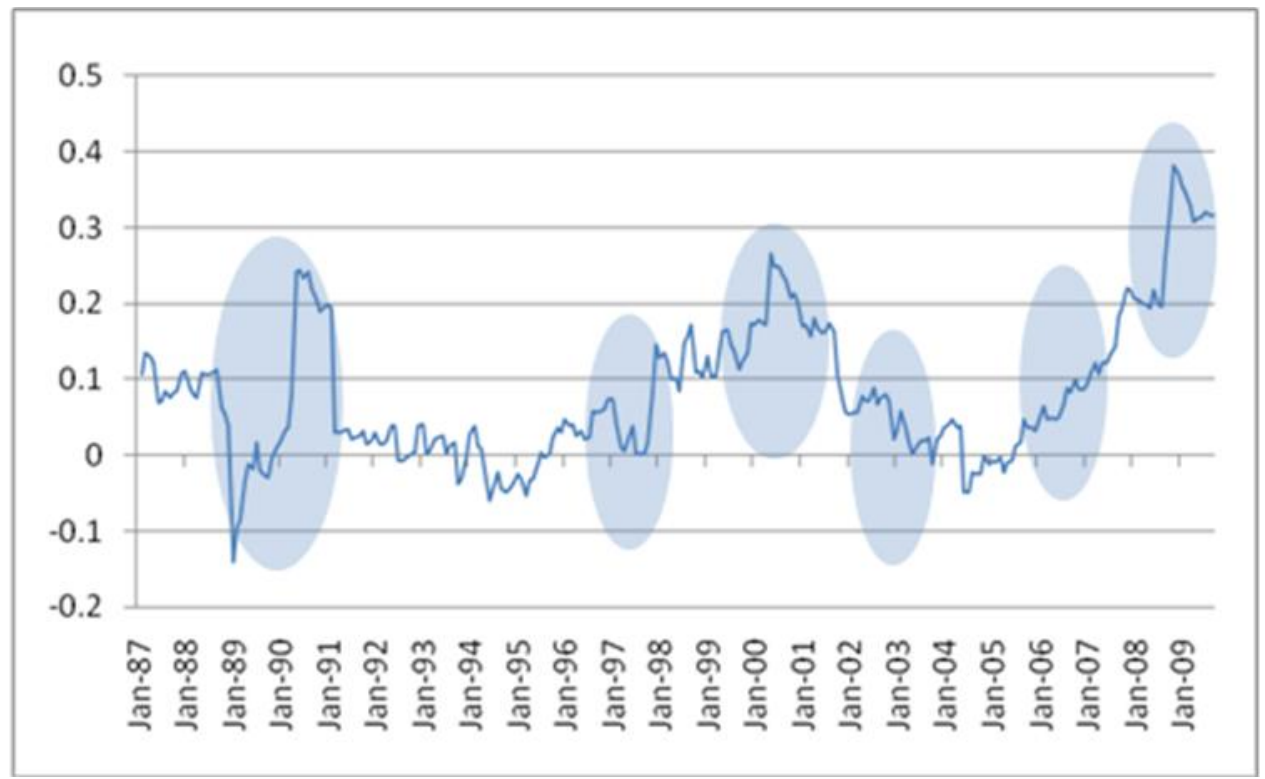

Time varying correlation between Canadian stock market index (S\&P/TSX 60) and crude oil.

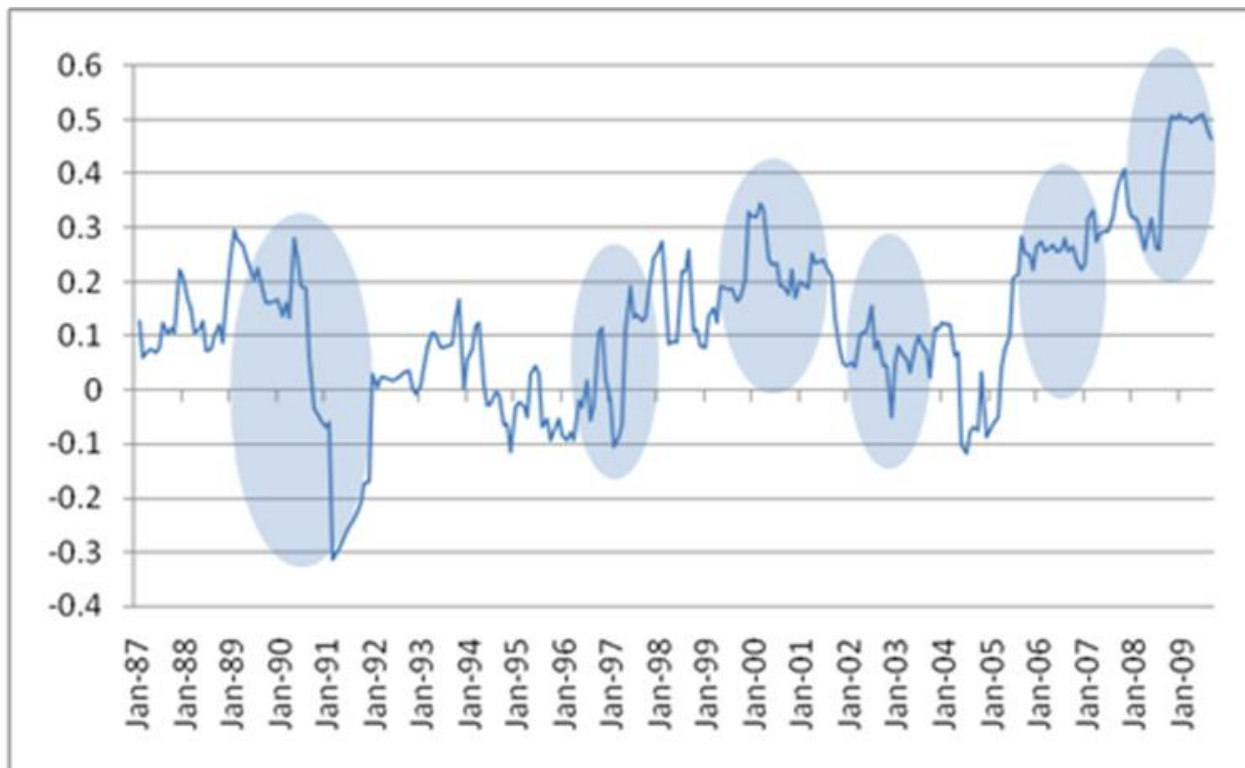


Time varying correlation between Mexican stock market index (MXIPC 35) and crude oil.

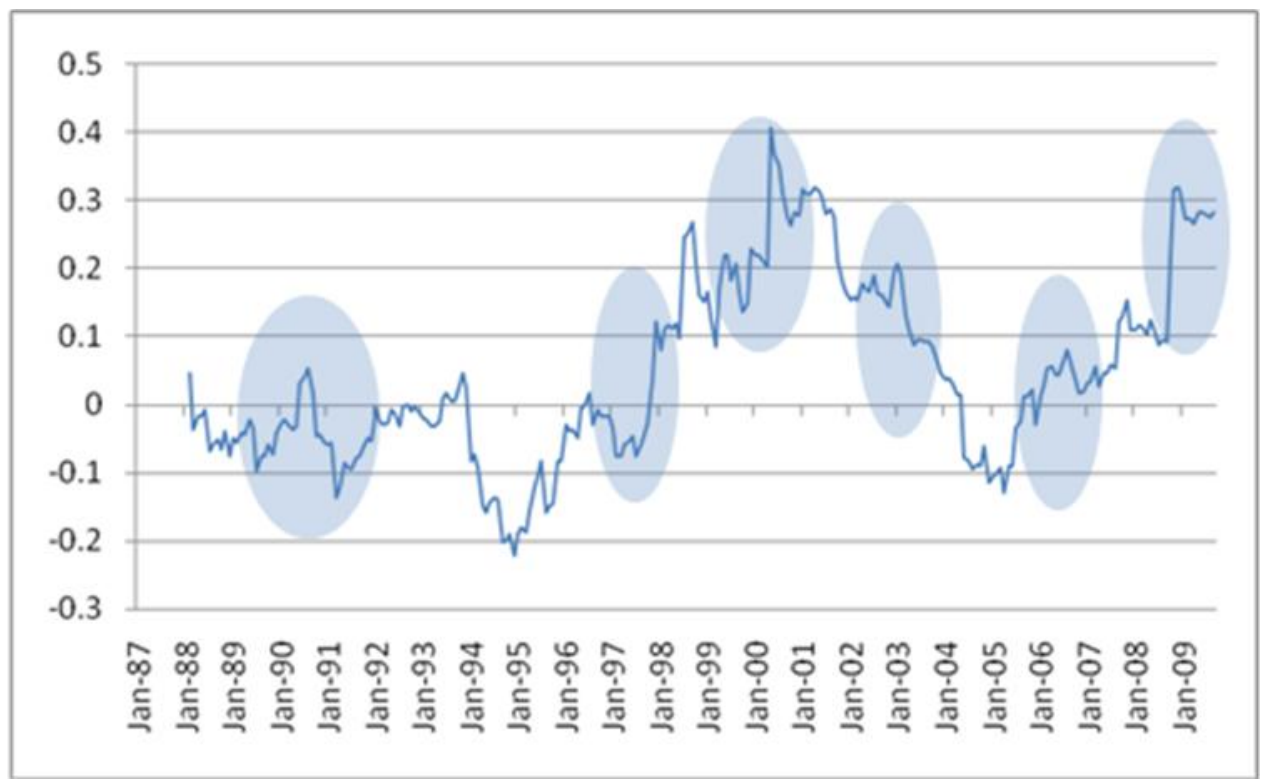

\section{b) Oil Importing Countries}

Time varying correlation between USA stock market index (Dow Jones Industrial) and crude oil.

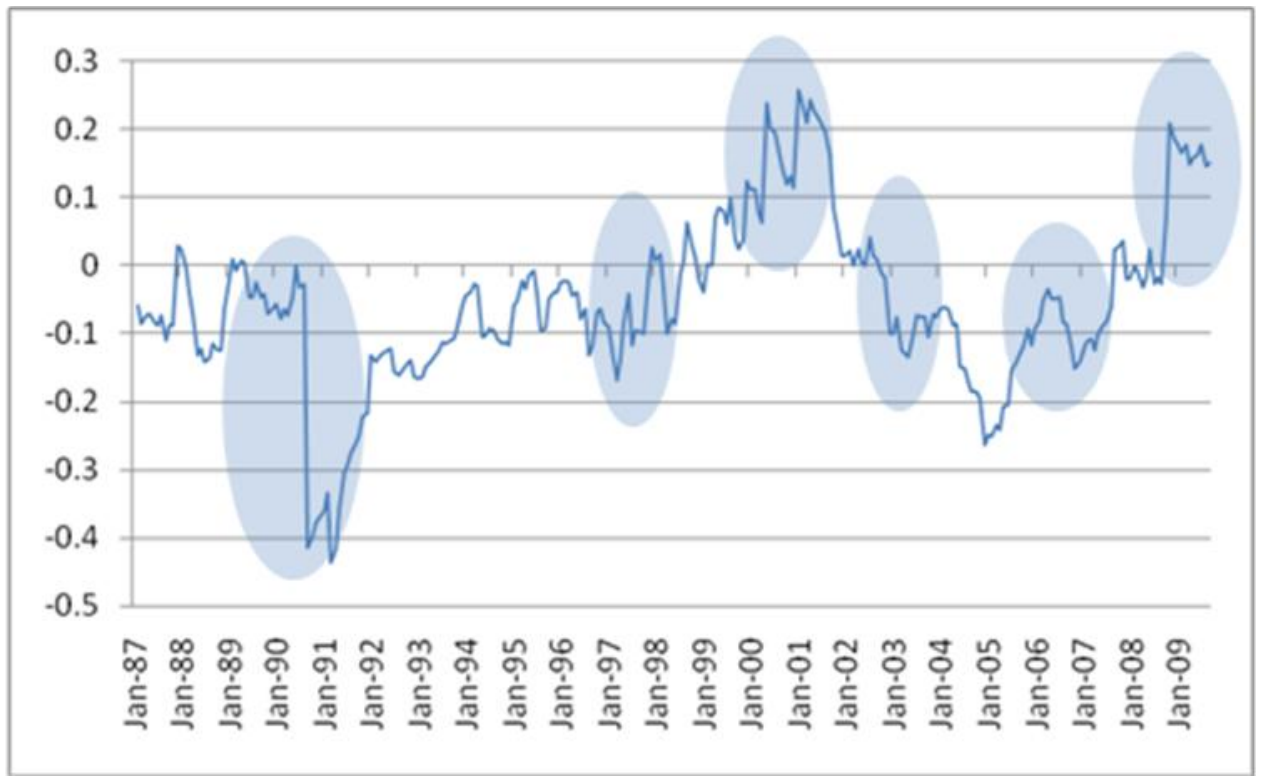


Time varying correlation between Netherlands stock market index (AEX General) and crude oil.

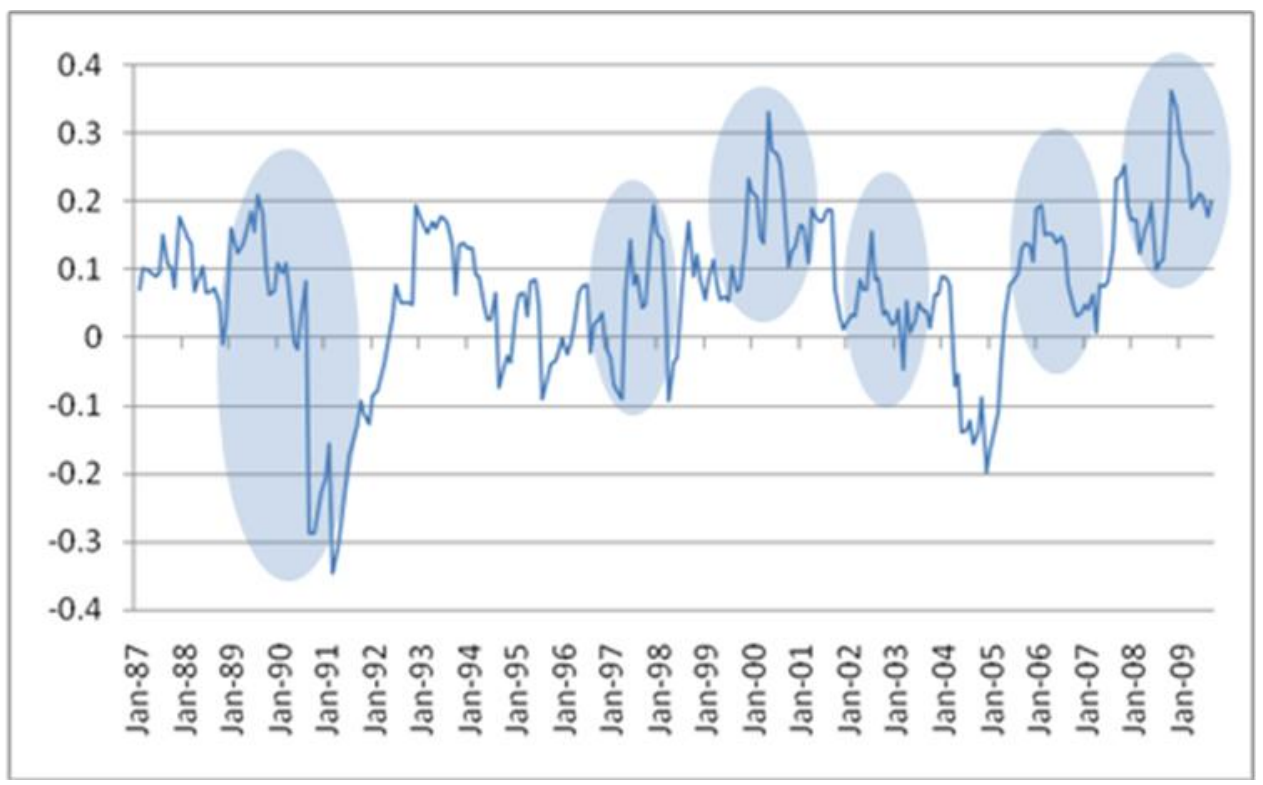

Time varying correlation between German stock market index (DAX 30) and crude oil.

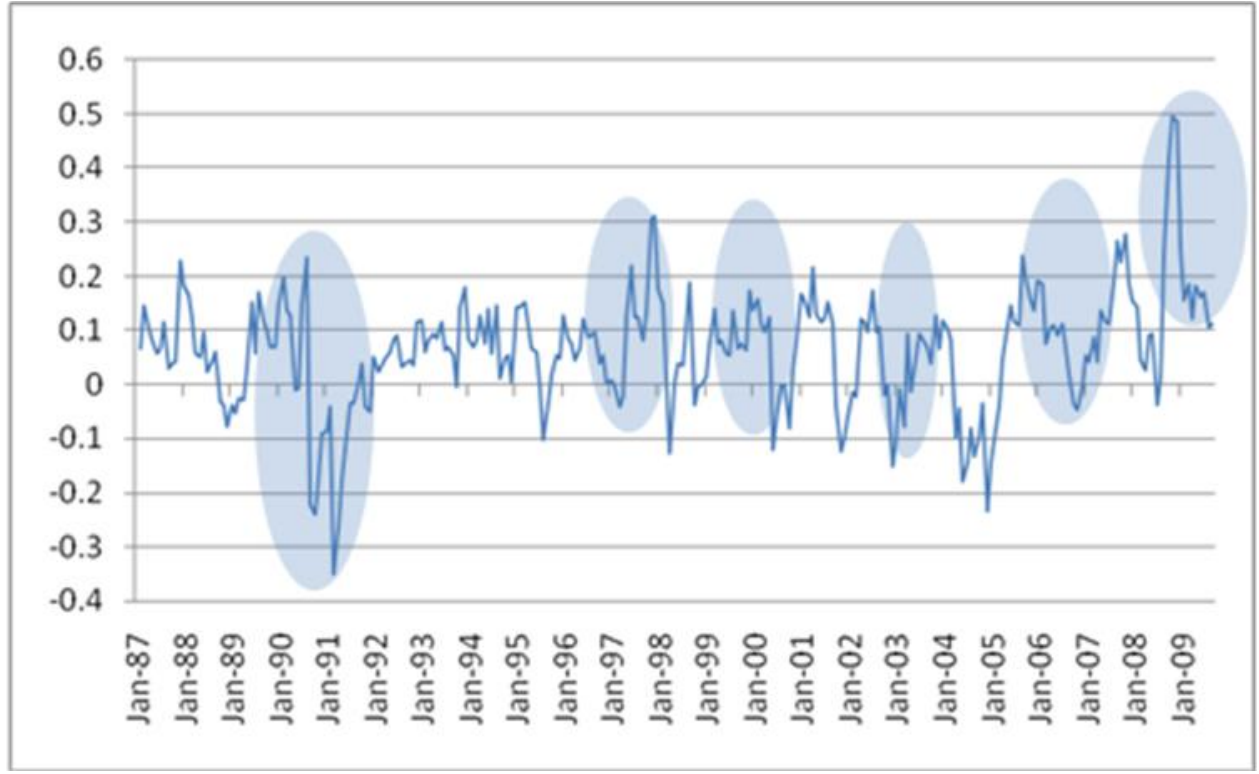


FIGURE 4: Dynamic Correlation between the lagged crude oil price and the stock market index, computed from the DCC-GARCH model with Student-t distribution as:

$$
\begin{gathered}
\mathbf{C}_{t}=\mathbf{Q}_{t}^{*-1 / 2} \mathbf{Q}_{t} \mathbf{Q}_{t}^{*-1 / 2}, \text { where } \\
\mathbf{Q}_{t}^{*-1 / 2}=\left(\begin{array}{cc}
q_{1,1, t}^{-1 / 2} & 0 \\
0 & q_{2,2, t}^{-1 / 2}
\end{array}\right) \\
\mathbf{Q}_{t}=(1-a-b) \overline{\mathbf{Q}}+a\left(\left(\begin{array}{c}
z_{1, t-1} \\
z_{2, t-1}
\end{array}\right)\left(\begin{array}{c}
z_{1, t-1} \\
z_{2, t-1}
\end{array}\right)^{\prime}\right)+b \mathbf{Q}_{t-1}
\end{gathered}
$$

\section{a) Oil Exporting Countries}

Time varying correlation between current month's Brazilian stock market index (Bovespa) and previous month's crude oil.

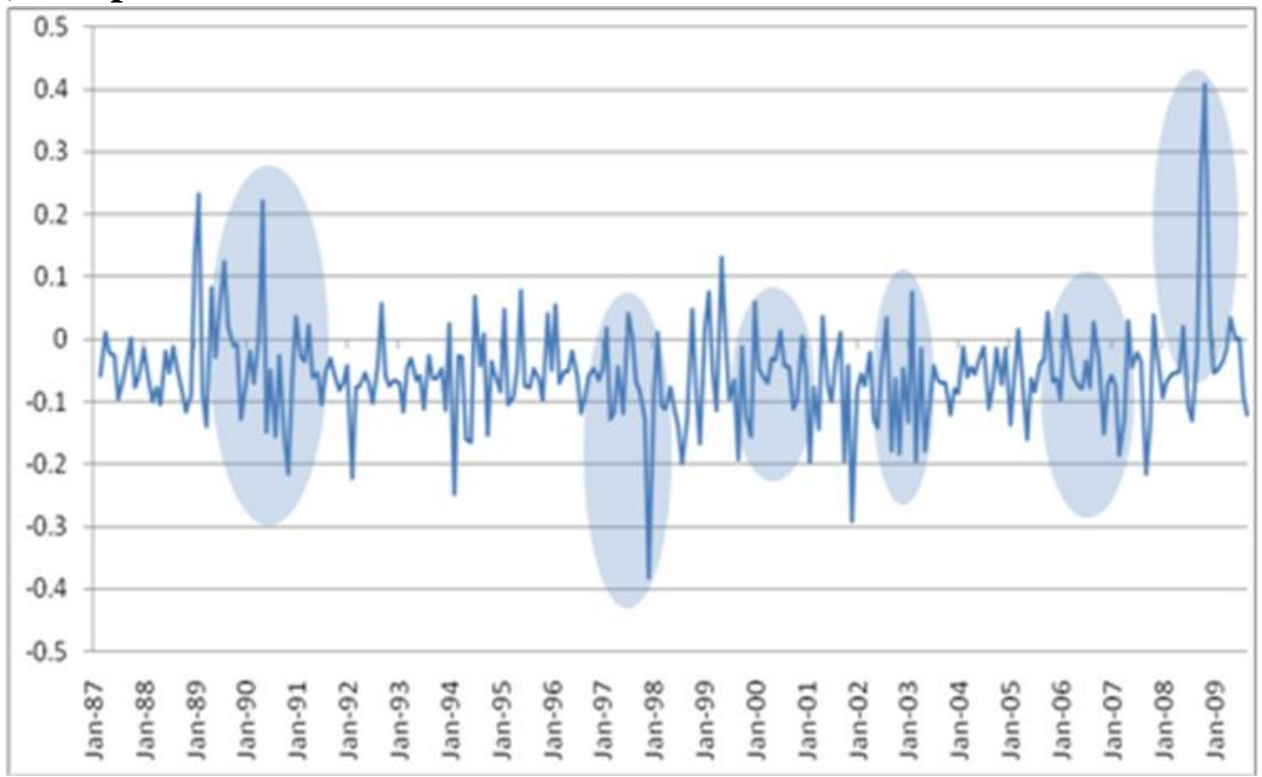

Time varying correlation between current month's Canadian stock market index (S\&P/TSX 60) and previous month's crude oil.

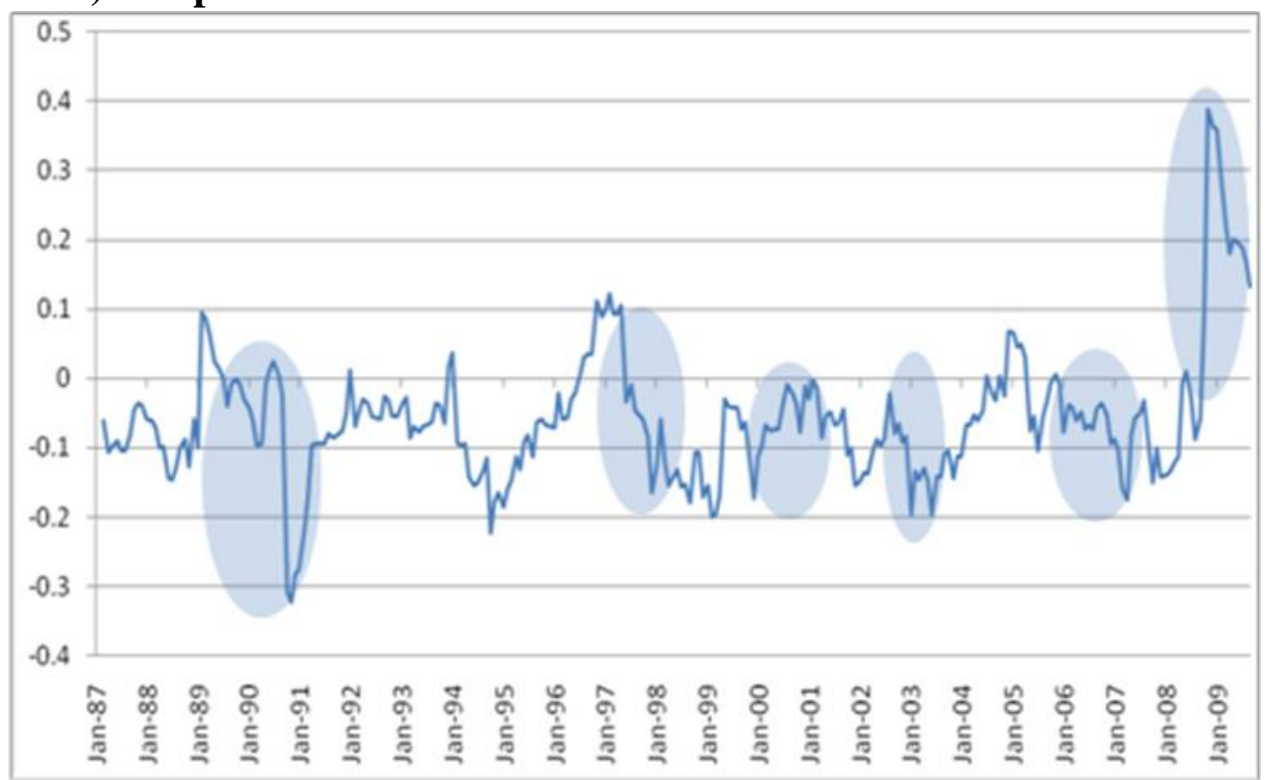


Time varying correlation between current month's Mexican stock market index (MXIPC 35) and previous month's crude oil.

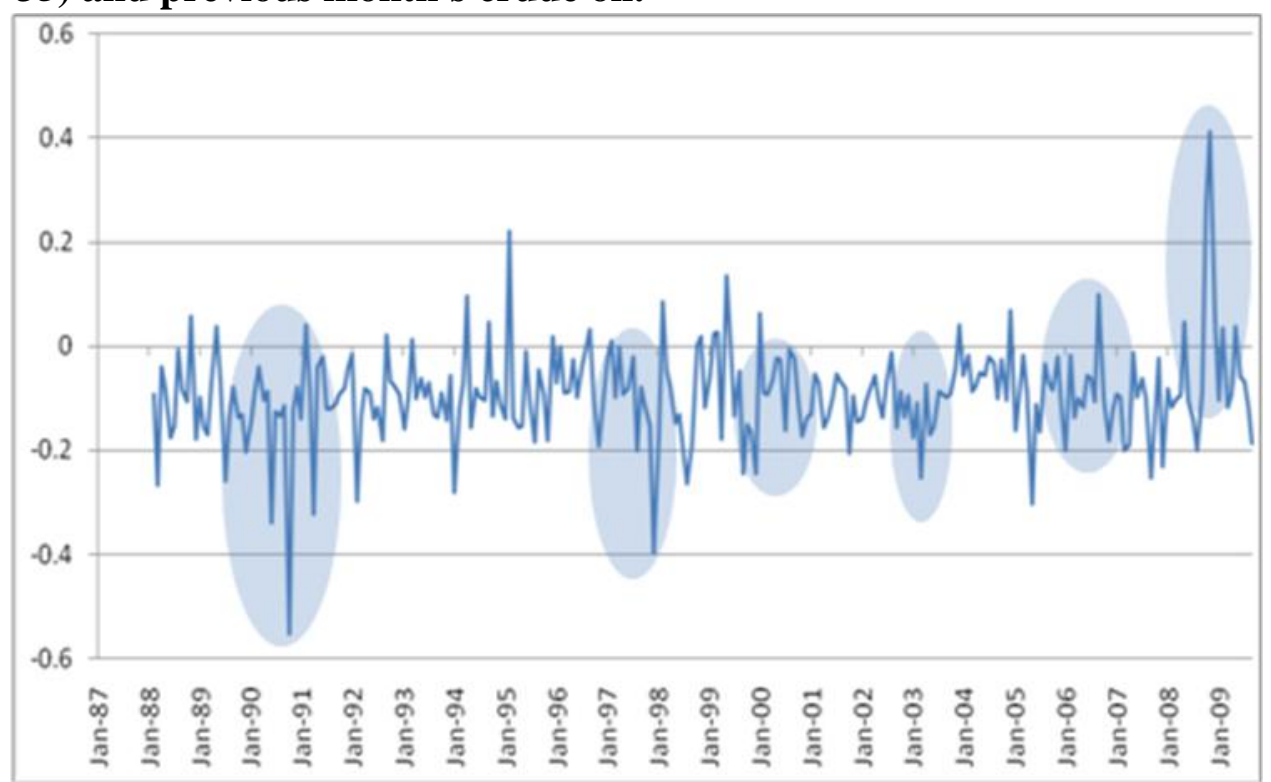

\section{b) Oil Importing Countries}

Time varying correlation between current month's USA stock market index (Dow Jones Industrial) and previous month's crude oil.

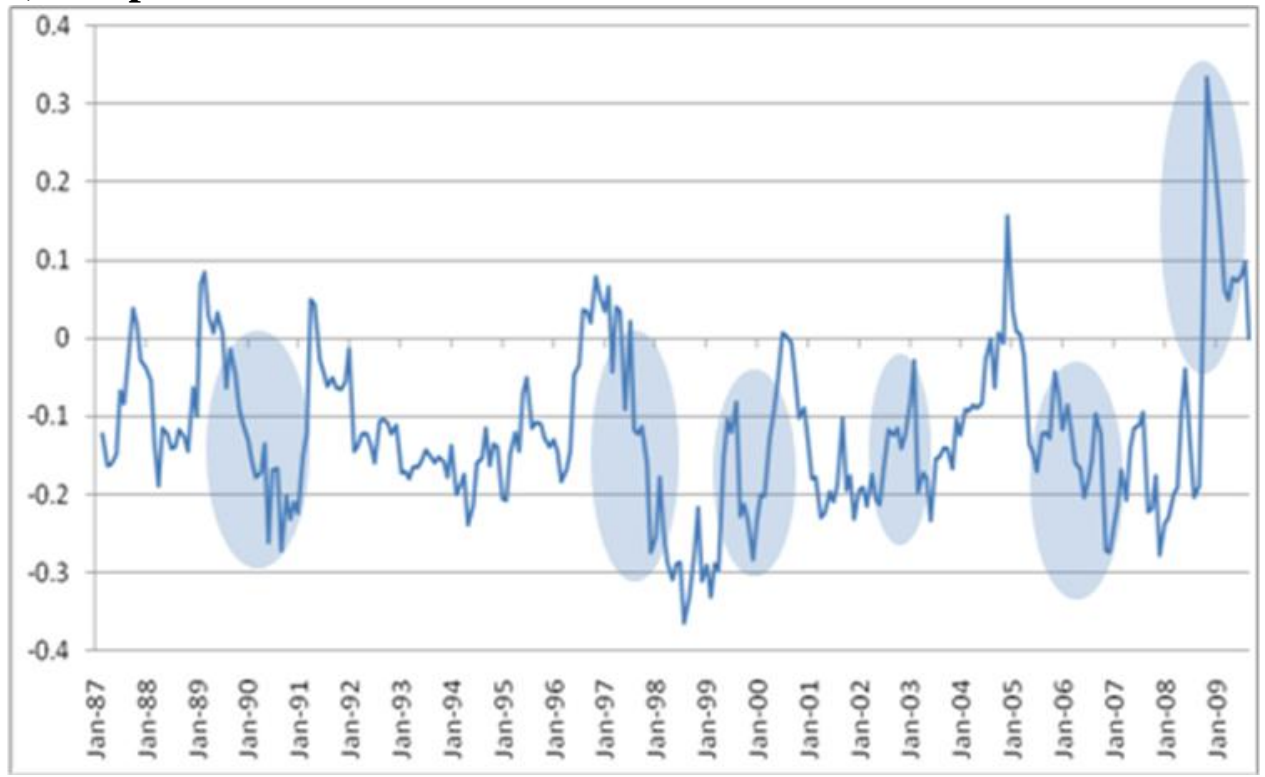


Time varying correlation between current month's Netherlands stock market index (AEX General) and previous month's crude oil.

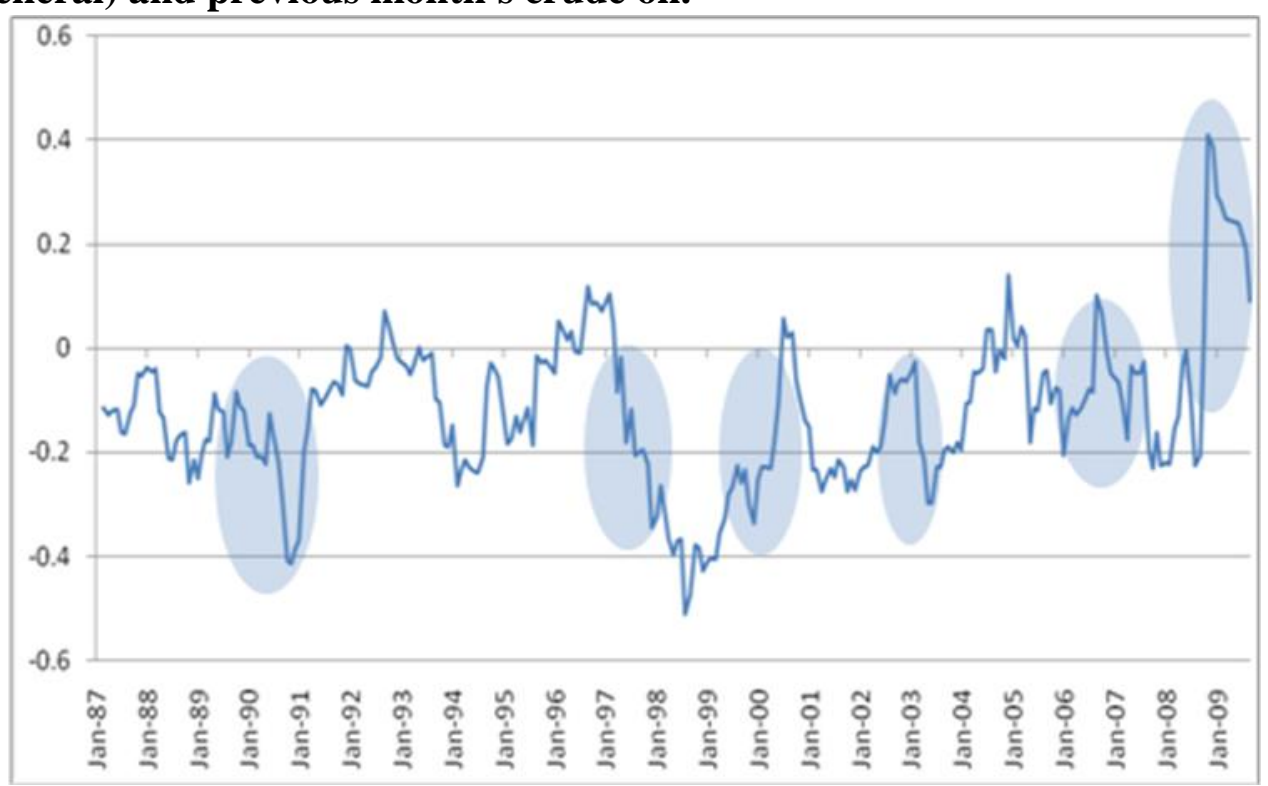

Time varying correlation between current month's German stock market index (DAX 30) and previous month's crude oil.

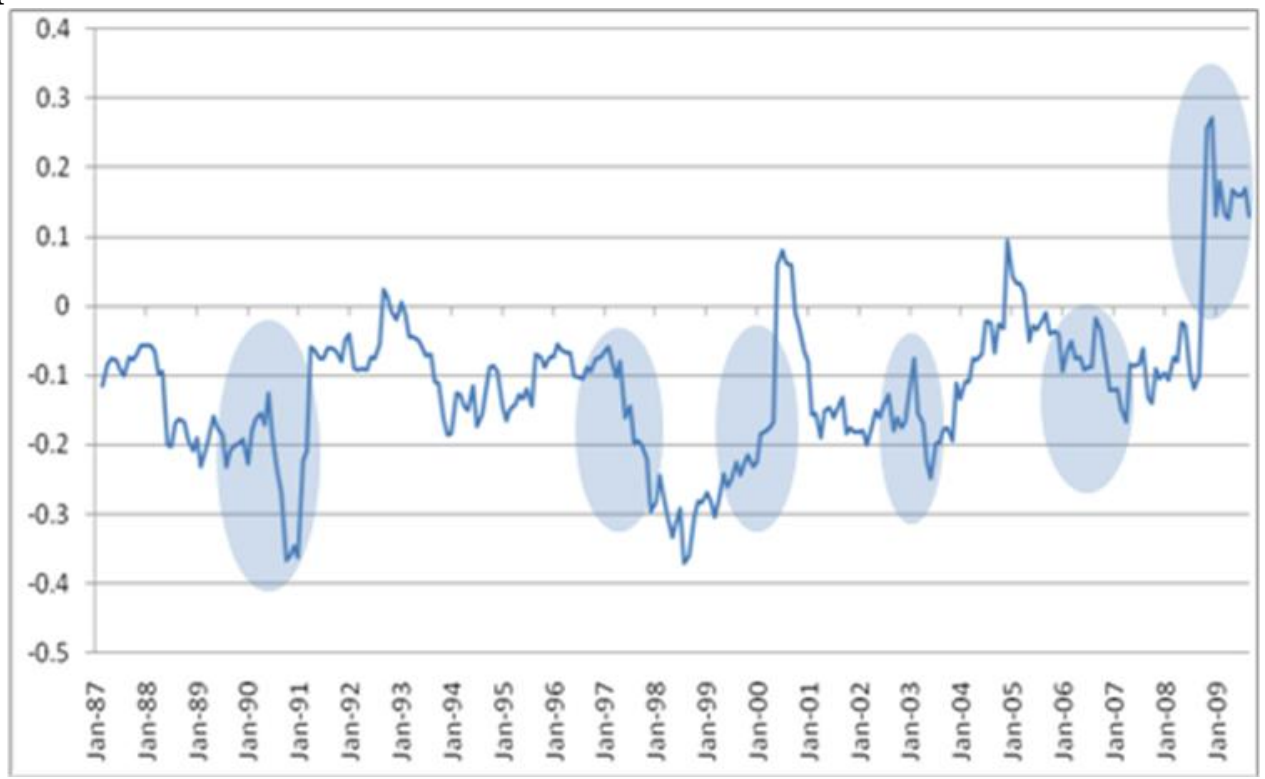


Tables

TABLE 1. Oil Price Chronology from 1987 to 2009.

Part A. The main events took place in the period 1987-1997.

\begin{tabular}{|c|c|c|c|c|c|c|c|c|c|c|c|}
\hline & 1987 & 1988 & 1989 & 1990 & 1991 & 1992 & 1993 & 1994 & 1995 & 1996 & 1997 \\
\hline January & $\begin{array}{l}\text { OPEC meeting } \\
\text { failure }\end{array}$ & & & & $\begin{array}{l}\text { US begin its } \\
\text { attack to Iraq }\end{array}$ & & & & $\begin{array}{l}\text { Gabon } \\
\text { withdraws } \\
\text { from OPEC }\end{array}$ & & \\
\hline \multicolumn{12}{|l|}{ February } \\
\hline \multicolumn{12}{|l|}{ March } \\
\hline April & & & & & & & & $\begin{array}{l}\text { Nigerian oil } \\
\text { w orkers go } \\
\text { on strike } \\
\text { resulting to a } \\
\text { decrease in } \\
\text { production }\end{array}$ & & \begin{tabular}{|l|} 
President \\
Clinton \\
approves the \\
sale of crude \\
oil from the \\
Strategic \\
Petroleum \\
Reserve
\end{tabular} & \\
\hline \multicolumn{12}{|l|}{ May } \\
\hline June & & \begin{tabular}{|l|} 
OPEC raises \\
production to \\
19.5 million \\
bbbld
\end{tabular} & & & & & & & & & \\
\hline \multicolumn{12}{|l|}{ July } \\
\hline August & & & & $\begin{array}{l}\text { Iraq invades } \\
\text { Kuw ait }\end{array}$ & & & & & & & \\
\hline \multicolumn{12}{|l|}{ September } \\
\hline October & & & & & & $\begin{array}{l}\text { Ecuador } \\
\text { withdraws } \\
\text { from OPEC }\end{array}$ & & & & & \\
\hline November & & & & & & & & & & & \begin{tabular}{|l|} 
OPEC agrees \\
to an increase \\
in its \\
production \\
ceiling \\
\end{tabular} \\
\hline December & & & & & $\begin{array}{l}\text { Soviet Union } \\
\text { collapses }\end{array}$ & & & & & & \\
\hline
\end{tabular}

Source: US Energy Information Administration. 
Part B. The main events took place in the period 1998-2009.

\begin{tabular}{|c|c|c|c|c|c|c|c|c|c|c|c|c|}
\hline & 1998 & 1999 & 2000 & 2001 & 2002 & 2003 & 2004 & 2005 & 2006 & 2007 & 2008 & 2009 \\
\hline January & \begin{tabular}{|l} 
Asian \\
economic \\
crisis
\end{tabular} & & & & $\begin{array}{l}\text { OPEC } \\
\text { decides to } \\
\text { cut quotas }\end{array}$ & & \multirow{4}{*}{$\begin{array}{l}\text { OPEC } \\
\text { decides to } \\
\text { cut quotas } \\
\text { at various } \\
\text { meetings }\end{array}$} & & & & $\begin{array}{l}\text { Rising } \\
\text { demand, } \\
\text { low spare } \\
\text { capacity } \\
\end{array}$ & \\
\hline February & & & & & & & & & \begin{tabular}{|l|} 
Militant \\
attacks in \\
Nigeria shut \\
dow $n$ more \\
than \\
600,000 \\
bbl/d of oil \\
production \\
\end{tabular} & & & \\
\hline March & & $\begin{array}{l}\text { OPEC cuts } \\
\text { quotas }\end{array}$ & \multirow{8}{*}{$\begin{array}{l}\text { OPEC oil } \\
\text { ministers ag } \\
\text { ree on an } \\
\text { increase in } \\
\text { oil } \\
\text { production }\end{array}$} & & & War in Iraq & & & & & & \\
\hline \multicolumn{12}{|l|}{ April } & \\
\hline May & $\begin{array}{l}\text { OPEC cuts } \\
\text { quotas at } \\
\text { various } \\
\text { meetings }\end{array}$ & & & & & & & & & & $\begin{array}{l}\text { President } \\
\text { Bush signs } \\
\text { into law a } \\
\text { bill that } \\
\text { temporarily } \\
\text { halts adding } \\
\text { oil to the } \\
\text { Strategic } \\
\text { Petroleum } \\
\text { Reserve }\end{array}$ & \\
\hline \multicolumn{12}{|c|}{ production } & \\
\hline \multicolumn{12}{|c|}{ production } & \\
\hline August & & & & & & & & \begin{tabular}{|l|} 
Hurricanes \\
Katrina, \\
Dennis and \\
Rita strike \\
\end{tabular} & & & & \\
\hline September & & & & $\begin{array}{l}9 / 11 \\
\text { Attacks }\end{array}$ & & & $\begin{array}{l}\text { Hurricane } \\
\text { Ivan strikes }\end{array}$ & & & & \begin{tabular}{|l} 
Hurricane \\
Gustav \\
strikes
\end{tabular} & \\
\hline \multicolumn{12}{|l|}{ October } & \\
\hline \multicolumn{12}{|l|}{ November } & \\
\hline December & & & & & $\begin{array}{l}\text { PdVSA } \\
\text { Srike in } \\
\text { Venezuela }\end{array}$ & $\begin{array}{l}\text { decides to } \\
\text { cut quotas } \\
\text { at various }\end{array}$ & & & & & $\begin{array}{l}\text { OPEC } \\
\text { decides to } \\
\text { cut quotas }\end{array}$ & \\
\hline
\end{tabular}

Source: US Energy Information Administration.

\section{TABLE 2: Main events and their corresponding oil price shock origin.}

\section{Event}

Iraq Invasion in Kuwait

First war in Iraq

Collapse of the Soviet Union

Asian Economic Crisis

Several oil production cuts by OPEC

Housing market boom

9/11 terrorist attack in US

PdVSA worker's strike

Second war in Iraq

Chinese economic growth

Global financial crisis
Year

1990 Precautionary demand

1991 Precautionary demand

1991 Precautionary demand

1997 Aggregate demand side

1998-1999 Supply side

2000 Aggregate demand side

2001 Precautionary demand

2002 Supply side

2003 Precautionary demand

2006-2007 Aggregate demand side

2008 Aggregate demand side

Note: Events were tied up to specific oil price shocks origins according to Kilian's (2009) and Hamilton's (2009) findings. 
TABLE 3. Summary of the findings - Contemporaneous correlations.

\begin{tabular}{|c|c|c|}
\hline Event & Oil price shock origin & Correlation sign \\
\hline $\begin{array}{l}\text { Iraq Invasion in Kuwait/ } \\
\text { First war in Iraq }\end{array}$ & Precautionary demand & negative \\
\hline Asian economic crisis & Aggregate demand-side shock & positive \\
\hline Housing market boom & Aggregate demand-side shock & positive \\
\hline Second war in Iraq & Precautionary demand & negative \\
\hline Chinese economic growth & Aggregate demand-side shock & positive \\
\hline Global financial crisis & Aggregate demand-side shock & positive \\
\hline
\end{tabular}

\section{TABLE 4. Summary of the findings - Lagged correlations.}

\begin{tabular}{|c|c|c|}
\hline Event & Oil price shock origin & Correlation sign \\
\hline $\begin{array}{l}\text { Iraq Invasion in Kuwait/ } \\
\text { First war in Iraq }\end{array}$ & Precautionary demand & negative \\
\hline Asian economic crisis & Aggregate demand-side shock & negative \\
\hline Housing market boom & Aggregate demand-side shock & negative \\
\hline Second war in Iraq & Precautionary demand & negative \\
\hline Chinese economic growth & Aggregate demand-side shock & negative \\
\hline Global financial crisis & Aggregate demand-side shock & positive \\
\hline
\end{tabular}

